\title{
The marine activities performed within the TOMO-ETNA experiment
}

Mauro Coltelli ${ }^{1, \star}$, Danilo Cavallaro ${ }^{1,2}$, Marco Firetto Carlino ${ }^{1}$, Luca Cocchi ${ }^{3}$, Filippo Muccini ${ }^{3}$, Antonino D’Alessandro ${ }^{4}$, Maria Eloisa Claude ${ }^{5}$, Clara Monaco², Jesús M. Ibáñez ${ }^{5}$, Fabrizio Zgur ${ }^{6}$, Domenico Patanè ${ }^{1}$, Cosmo Carmisciano ${ }^{3}$, Giuseppe D’Anna ${ }^{4}$, Maria Teresa Pedrosa Gonzales ${ }^{5}$, Teresa Teixidó ${ }^{5}$, Roberto D’Anna ${ }^{4}$, Gioacchino Fertitta ${ }^{4}$, Giuseppe Passafiume ${ }^{4}$, Stefano Speciale ${ }^{4}$, Fausto Grassa ${ }^{7}$, Aristomenis P. Karageorgis ${ }^{8}$, Lorenzo Sormani $^{6}$, Lorenzo Facchin ${ }^{6}$, Giampaolo Visnovic ${ }^{6}$, Diego Cotterle ${ }^{6}$, Rita Blanos ${ }^{6}$, Paolo Mansutti ${ }^{6}$, Attilio Sulli ${ }^{9}$, Fabrizio Cultrera $^{2}$, Francisco Carrión ${ }^{5}$, Salvatore Rapisarda ${ }^{1}$

${ }^{1}$ Istituto Nazionale di Geofisica e Vulcanologia, Sezione di Catania, Osservatorio Etneo, Catania, Italy

${ }^{2}$ Università di Catania, Dipartimento di Scienze Biologiche, Geologiche e Ambientali, Catania, Italy

${ }^{3}$ Istituto Nazionale di Geofisica e Vulcanologia, Sezione Roma 2, Rome, Italy

${ }^{4}$ Istituto Nazionale di Geofisica e Vulcanologia, Centro Nazionale Terremoti, Rome, Italy

${ }^{5}$ Instituto Andaluz de Geofisica, Universidad de Granada, Granada, Spain

${ }^{6}$ Istituto Nazionale di Oceanografia e Geofisica Sperimentale, Sgonico (Trieste), Italy

${ }^{7}$ Istituto Nazionale di Geofisica e Vulcanologia, Sezione di Palermo, Palermo, Italy

${ }^{8}$ Hellenic Centre for Marine Research, Institute of Oceanography, Athens, Greece

${ }^{9}$ Università di Palermo, Dipartimento di Scienze della Terra e del Mare, Palermo, Italy

\section{Article history}

Received March 17, 2016; accepted May 30, 2016.

Subject classification:

Scientific cruise report, Marine geophysical data acquisition, Etna offshore, Ionian and Tyrrhenian Seas.

\section{ABSTRACT}

The TOMO-ETNA experiment was planned in order to obtain a detailed geological and structural model of the continental and oceanic crust beneath Mt. Etna volcano and northeastern Sicily up to the Aeolian Islands (southern Italy), by integrating data from active and passive refraction and reflection seismic methodologies, magnetic and gravity surveys. This paper focuses on the marine activities performed within the experiment, which have been carried out in the Ionian and Tyrrhenian Seas, during three multidisciplinary oceanographic cruises, involving three research vessels ("Sarmiento de Gamboa", "Galatea" and "Aegaeo") belonging to different countries and institutions. During the offshore surveys about 9700 air-gun shots were produced to achieve a high-resolution seismic tomography through the wide-angle seismic refraction method, covering a total of nearly $2650 \mathrm{~km}$ of shooting tracks. To register ground motion, 27 ocean bottom seismometers were deployed, extending the inland seismic permanent network of the Istituto Nazionale di Geofisica e Vulcanologia (INGV) and a temporary network installed for the experiment. A total of $1410 \mathrm{~km}$ of multi-channel seismic reflection profiles were acquired to image the subsurface of the area and to achieve a $2 \mathrm{D}$ velocity model for each profile. Multibeam sonar and sub bottom profiler data were also collected. Moreover, a total of $2020 \mathrm{~km}$ of magnetic and $680 \mathrm{~km}$ of gravity track lines were acquired to compile magnetic and gravity anomaly maps offshore Mt. Etna volcano. Here, high-resolution images of the seafloor, as well as sediment and rock samples, were also collected using a remotely operated vehicle.

\section{Introduction}

The TOMO-ETNA (seismic TOMOgraphy at ETNA volcano and surrounding areas) experiment was planned to image the roots of Etna volcano and the crustal structures of northeastern Sicily through an active seismic source survey. It is part of the "Task 5.3 Mt. Etna structure" of the European Union FP7 project "MED-SUV" (MEDiterranean SUpersite Volcanoes), and was also performed with the resources of the EU EUROFLEETS 2 project “MED-SUV.ISES” [Ibáñez et al. 2016a, 2016b, in this volume]. Moreover, other funding agencies from Spain (COCSABO), Italy (INGV) and 
Germany (GIPP) supported this experiment [Ibáñez et al. 2016a, in this volume]. In detail, the TOMO-ETNA experiment was scheduled to obtain a geological and structural model of the continental and oceanic crust beneath Mt. Etna and northeastern Sicily, up to the Aeolian Archipelago, using a multidisciplinary approach consisting of active and passive seismic, magnetic and gravity surveys. The main goal of the experiment was to obtain a high-resolution tomography, in velocity and attenuation, of the crust concerning this region of Sicily, more accurate than that currently available [MartínezArévalo et al. 2005; Patanè et al. 2006, 2011; De Gori et al. 2011], to better define the regional tectonic setting and the physical processes controlling magma ascent beneath Mt. Etna and Aeolian Island volcanoes, for improving the knowledge in both seismic and volcanic hazard assessment in such a densely populated area.

The achievement of these objectives was based on the integration of marine and inland geophysical data. To this end, a set of seismic stations were installed either inland (Mt. Etna and surrounding areas, northeastern Sicily and the Aeolian Islands) and in the Ionian and Tyrrhenian Seas (offshore Mt. Etna and the Aeolian Islands), to record active (air-gun shots generated offshore) and passive (natural seismicity; see also Barberi et al. [2016] in this volume) seismic data (see also Ibáñez et al. [2016b] in this volume).

The marine areas offshore Mt. Etna, northeastern Sicily and the Aeolian Islands have been previously investigated, with the main objective of understanding the complex geodynamic setting of this central Mediterranean area between African and European plates [Nicolich et al. 2000; Finetti 2003; Pareschi et al. 2006; Chiocci et al. 2011; Polonia et al. 2011; Argnani et al. 2013; Gross et al. 2016]. In this context, the TOMO-ETNA experiment represents an important attempt to improve the knowledge of the geological evolution of this area, through a large amount of new data coming from multidisciplinary geophysical methods.

The TOMO-ETNA experiment was carried out between June and November 2014. It entailed two phases (June-July and October-November), during which the scientific activities were performed both inland and offshore.

In the first phase of the experiment two oceanographic cruises were carried out. The first was accomplished from June 24 to July 20, 2014, on board the research vessel (R/V) "Sarmiento de Gamboa" by CSIC-UTM (Consejo Superior de Investigaciones Científicas - Unidad de Tecnología Marina, Spain), with the support of the ship "Levanzo" by Italian Navy as patrol vessel. The first leg of this cruise was dedicated to producing seismic signals (air-gun shooting) for the wide- angle seismic (WAS) refraction method, to obtain a new high-resolution tomography of the study area [Ibáñez et al. 2016a, in this volume]. The second leg sought to collect multi-channel seismic (MCS) reflection profiles to image the crustal seismo-stratigraphic and structural features of the area, down to the Moho discontinuity [see Firetto Carlino et al. 2016, in this volume] and to infer a $2 \mathrm{D}$ velocity model for each profile; the integration between WAS and MCS methods will strengthen the geological interpretation.

The second cruise was undertaken between June 25 to July 3, 2014, offshore Mt. Etna volcano on board the hydrographic vessel (H/V) "Galatea" by Italian Navy: magnetic data were acquired to compile a magnetic anomaly map and to support the interpretation of the seismic data. Moreover, remotely operated vehicle (ROV) dives were accomplished to collect several seafloor images and samples regarding some specific features of high geological interest offshore Mt. Etna [see Cavallaro et al. 2016, in this volume].

During both the cruises, several broadband and short-period ocean bottom seismometers (OBSs) were deployed, either in the Ionian and Tyrrhenian Seas, to record the ground motion produced by the air-gun shots and the natural seismicity [Barberi et al. 2016, Ibáñez et al. 2016b, in this volume], extending the Istituto $\mathrm{Na}-$ zionale di Geofisica e Vulcanologia (INGV) permanent seismic network. For the same purpose, a series of removable geophones (both short-period and broadband) were positioned inland on Mt. Etna volcano, in northeastern Sicily and surrounding areas. Most of the OBSs were recovered by the R/V "Sarmiento de Gamboa" at the end of the cruise, with the exception of two broadband sensors, that were left on the seafloor to record natural seismicity for a longer time span. At the end of this phase the inland temporary short-period geophones were removed as well, whereas the broadband geophones were kept in operation until the end of October 2014 [Ibáñez et al. 2016b, in this volume].

The marine activities of the second phase of the experiment were carried out from November 19 to 26, 2014, onboard of the R/V "Aegaeo" by HCRM (Hellenic Centre for Marine Research, Greece). During this cruise additional MCS lines were collected in both the Ionian and Tyrrhenian Seas to detail with higher resolution the shallower stratigraphic and structural features offshore Mt. Etna and the Aeolian Islands [Firetto Carlino et al. 2016, in this volume]. At the end of this cruise the two broadband OBSs were also recovered.

Finally, between June 17 and 23, 2015, an extension of the H/V "Galatea" research cruise was carried out offshore Mt. Etna, using the same vessel, to acquire additional magnetic data and perform a detailed gravity 
survey, which was not previously accomplished due to technical issues.

This paper represents the scientific/technical report of the three oceanographic cruises carried out within the TOMO-ETNA experiment. It describes in detail the cruises and geophysical surveys planning, the main characteristics of the vessels, technical specifications of the equipment, data acquisition and on board organization. It represents one of 11 papers that make up a special volume explaining the multidisciplinary topics and some preliminary results of the experiment [Ibáñez et al. 2016a]. A detailed description of the acquisition procedures, main data processing steps and preliminary results of MCS data, as well as of magnetic and ROV surveys are shown in Firetto Carlino et al. [2016, in this volume] and Cavallaro et al. [2016, in this volume], respectively.

\section{Planning}

\subsection{Negotiation and organization processes}

The organization of the marine activities of the TOMO-ETNA experiment, performed using three oceanographic research vessels and one military patrol ship, needed a complex negotiation with several multinational civil and military institutions to achieving the technical and administrative tasks.

After receiving the grants for the geophysical experiment from several agencies and institutions, as reported in the introduction and described in Ibáñez et al. [2016a, in this volume], the next step was to find the scientific equipment to accomplish the planned activities and obtain the required authorization to perform the experiment in the study areas.

Since the activities of the TOMO-ETNA experiment had to cover a wide marine area (more than 15,000 $\mathrm{km}^{2}$ ) for a long time span (overall almost two months) with possible impact (considering also the $3 \mathrm{~km}$ long streamer employed and the high-power air-gun shooting operations) on several marine civil (fishing, cargo and ferryboat traffic, etc.) and military activities, we needed to organize the cruises with the strategic support of the Italian Navy, which represents the most appropriate naval operator for managing safety, traffic control and authorizations issues.

Since 2005, the INGV and most of the major Italian research institutes involved in marine science have signed a scientific agreement with the Italian Navy, named CONAGEM (National Marine Geophysics Coordination), with the goal of achieving the cooperation among different partners ensuring the sharing of data and results. More recently, the General Command of the Italian Navy, through an agreement called "dual use", further promoted the cooperation with research institutes. Within this agreement, the Italian Navy aided the TOMO-ETNA experiment by supplying vessels and specialized crews to acquire the geophysical data and support the oceanographic cruises by guaranteeing the safety to navigation.

The cooperation with the Italian Navy involved several meetings in the military bases of La Spezia and Augusta to plan the offshore technical-scientific activities as well as the periods of interdiction to navigation in the surveyed areas. A catamaran for oceanographic surveys ("Galatea") was provided to acquire magnetic, gravity and ROV data. Moreover, to ensure safety in the investigation area, characterized by intense maritime traffic, the Italian Navy supplied a patrol vessel (ship "Levanzo") to monitor the marine area during the first phase of the MCS acquisition, done using a $3 \mathrm{~km}$ long seismic streamer.

The request of authorization for marine scientific operations in the exclusive economic zones of Italy for the R/V "Sarmiento de Gamboa" (CSIC-UTM, Spain), was negotiated by the University of Granada and INGV personnel with Spanish and Italian Foreign Offices. During the first phase of the experiment (June-July 2014), the Italian Navy together with the Italian Cost Guard interdicted the navigation in the surveyed areas. During the second phase (October-November 2014), the request of authorization for the offshore activities for the R/V "Aegaeo" (HCMR, Greece), was negotiated by INGV personnel with Greek and Italian Foreign Offices. The practice of interdicting navigation in the surveyed areas was carried out by INGV personnel with the Italian Cost Guard command of Messina.

To achieve the objective of crustal imaging planned for the TOMO-ETNA experiment, a set of expensive and complex geophysical equipment was employed. Negotiations with Spanish and Italian institutions, having marine geophysical exploration equipment and a long experience in marine geophysical survey, were conducted for such purpose.

The CSIC-UTM in Barcelona (Spain), which provided its modern and well equipped R/V "Sarmiento de Gamboa" through the COCSABO and EUROFLEETS 2 projects, was contacted by personnel of University of Granada and INGV for using OBSs, air-guns and digital hydrophone streamer with the objective to image the subsurface as deep as possible.

The Istituto Nazionale di Oceanografia e Geofisica Sperimentale (OGS) of Trieste (Italy), was contacted by INGV scientists to have access to its portable very high resolution seismic system, comprising a digital streamer and an air-guns array, to be embarked on the R/V "Aegaeo" (HCRM, Greece), available through EUROFLEETS 2 projects, for imaging the volcano-tectonic structures 
at shallow depth with high resolution.

The "OBS Lab" of INGV in Gibilmanna (Italy), was involved to supply part of the OBSs for the TOMO-ETNA experiment. It provided some broadband OBSs with hydrophone; moreover, starting from an already developed prototype, it built 10 new short-period OBSs to be deployed in both the Ionian and Tyrrhenian Seas. The Geophysics and Marine Technologies unit of La Spezia (Italy), was also involved to provide its marine geophysical instruments (ROV, magnetometer and gravimeter) and the scientific personnel to perform data acquisition on board. To pilot the ROV during the dives, an external technician by Subonica was involved. Unfortunately, the gravimeter was not available in both the two phases of the experiment, due to its maintenance in USA; nevertheless, because of the high geophysical importance of the gravity survey within the experiment, an extension of the H/V "Galatea” cruise was requested to the Italian Navy and promptly obtained for summer 2015.

For more information on the institutions involved within the TOMO-ETNA experiment, as well as the negotiation processes and agreements with different research and civil agencies, see Ibáñez et al. [2016a, in this volume].

\subsection{Marine scientific activities}

All the scientific surveys carried out during the oceanographic cruises of the TOMO-ETNA experiment were planned taking into account the available shiptime (for each $\mathrm{R} / \mathrm{V}$ ) and the eventual occurrence of the typical issues concerning the marine research activities, mainly related to weather and sea conditions and technical problems.

A fundamental step of the planning phase was to identify the OBS deployment sites for a suitable choice of the sea routes for WAS data acquisition, taking also into account the geometry of temporary and permanent seismic networks inland. In particular, the distribution of the OBSs was designed to uniformly cover the region of interest and to align the stations with the inland INGV permanent and temporary seismic networks [Ibáñez et al. 2016b, in this volume].

It was planned to deploy about 30 OBSs (both broadband and short-period, belonging to both INGV and CSIC-UTM) in both the Ionian and Tyrrhenian Seas. The OBSs deployment locations were chosen on the basis of water depth $(>200 \mathrm{~m}$ for INGV short-period sensors and $>1000 \mathrm{~m}$ for the CSIC-UTM ones), seabed morphology (slope $\geq 6 \%$ and near-canyon areas were avoided) and distance to the coast (Figure 1). Thus, existing high-resolution bathymetries of the Ionian and Tyrrhenian Seas were carefully analyzed. The presence of fishing activity that could obstruct the scientific operations and/or damage the technical equipment was also evaluated. The location of the broadband OBSs was set as close as possible to the offshore extension, either in the Ionian and Tyrrhenian Seas, of inland active faults on the basis of previous published papers [Lanzafame and Bousquet 1997; De Guidi et al. 2013, and references therein]. The location for per-

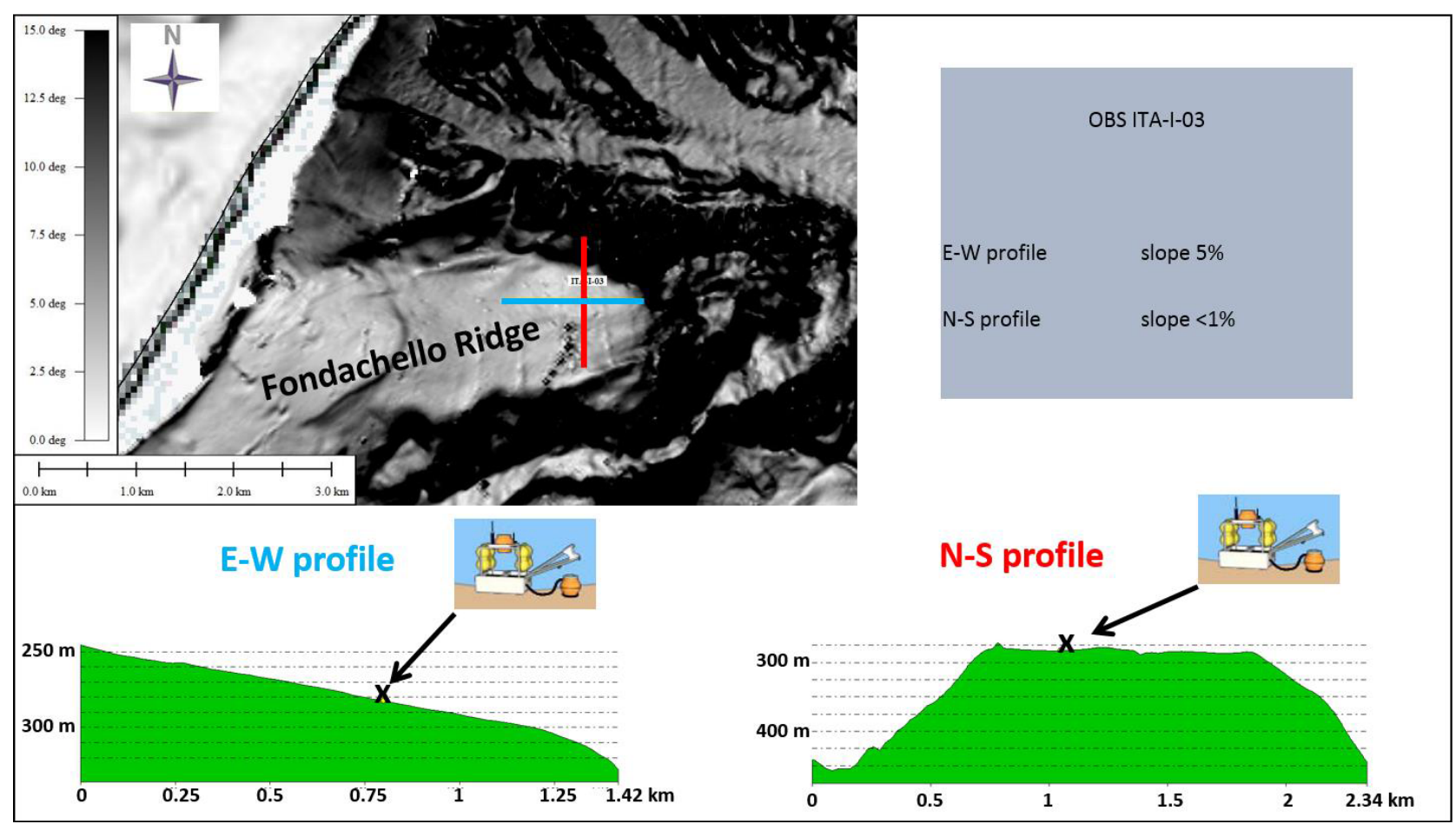

Figure 1. Example of planning for the OBS locations on the basis of the slope map. 


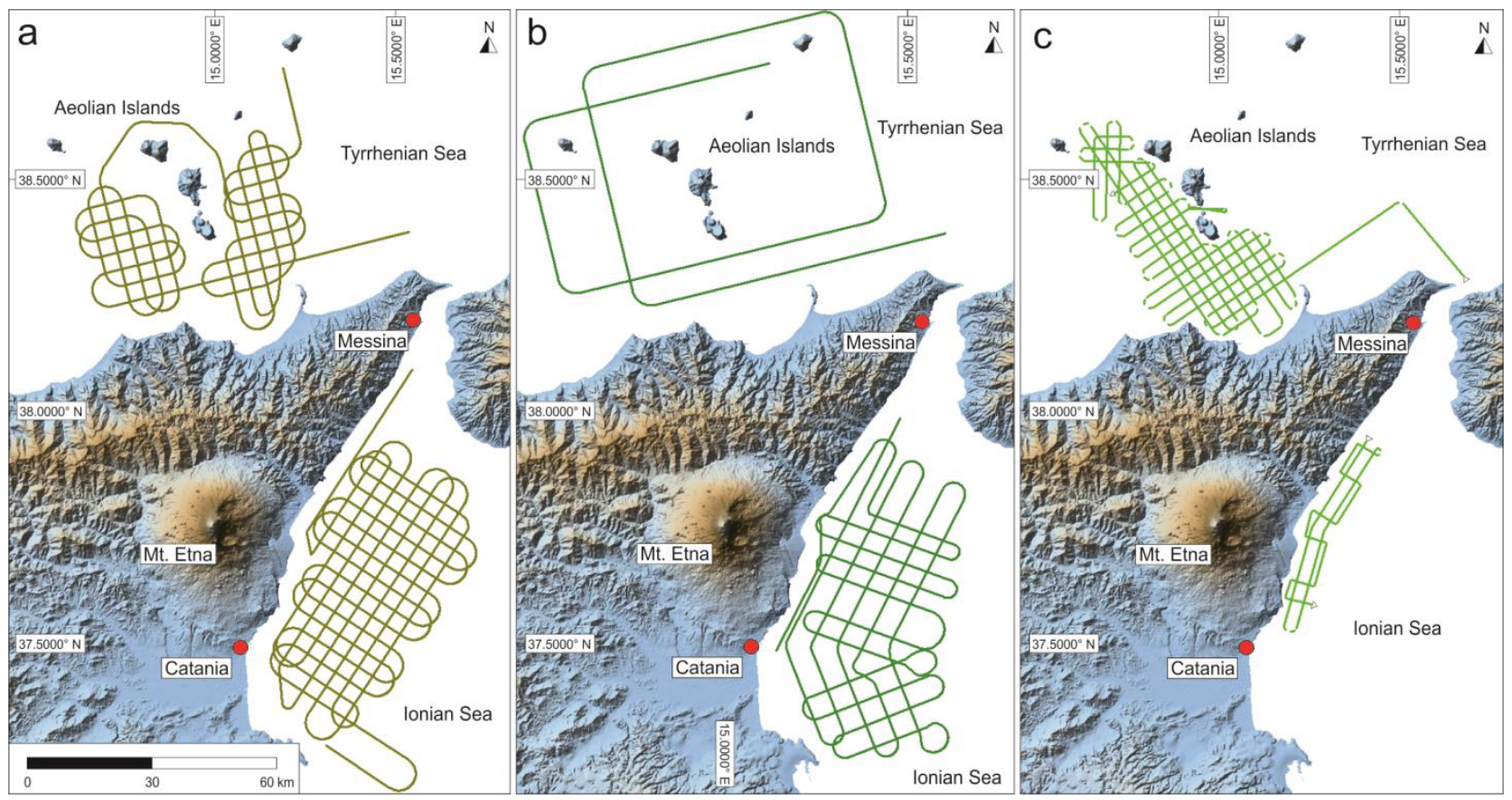

Figure 2. Planned seismic tracks: (a) WAS and (b) MCS by the R/V "Sarmiento de Gamboa"; (c), MCS by the R/V "Aegaeo".

forming the OBS "rosette test" (acoustic transponder tests) was also opportunely evaluated. It should be performed before dropping the OBSs, at a greater depth than the deepest OBS planned, to verify the correct working of the acoustic transponders, installed inside each OBS, during their recovery.

Three days were scheduled for the deployment of the CSIC-UTM OBSs and two for the INGV ones, through the oceanographic vessels "Sarmiento de Gamboa" and "Galatea", respectively. Additional 3-4 days were dedicated to the OBSs recovery operations at the end of the R/V "Sarmiento de Gamboa" cruise. To record the natural seismicity of the area for a longer time, it was decided to recover the two INGV broadband OBSs later, during the second phase of the experiment, through the R/V "Aegaeo".

WAS shooting tracks were designed taking into account various parameters, such as the available ship time, cruise speed, energizing power of the system, OBSs and inland seismic network locations, water depth, distance to the coast, eventual presence of maritime traffic, etc. A regular grid of $4 \mathrm{~km}$ spaced lines, longitudinal and orthogonal to the coast, for a total route of about $2000 \mathrm{~km}$, was designed to be accomplished in about 9 days (Figure 2a).

The planning of MCS tracks was further influenced by other issues due to the employment of a $3 \mathrm{~km}$ long streamer, in terms of navigation and equipment security. Moreover, the seismic lines were positioned to investigate features of particular geological interest offshore Mt. Etna and around the Aeolian Islands, taking into account previous studies [Pareschi et al. 2006;
Chiocci et al. 2011; Argnani et al. 2013; De Guidi et al. 2013 , and references therein]. A total of some $1000 \mathrm{~km}$ of seismic profiles in 8 days and $900 \mathrm{~km}$ in 7 days were planned to be acquired, longitudinally and orthogonally to the coast, on board the R/Vs "Sarmiento de Gamboa" and "Aegaeo", respectively (Figures $2 \mathrm{~b}$ and $2 \mathrm{c}$ ). In the event that MCS routes should be carried out slower/ faster than scheduled, some routes to delete/add were also planned.

To define the right parameters of the acoustic sources and choose the best configuration for WAS and MCS signals acquisition, several scientific meetings were carried out at the Osservatorio Etneo (INGV-OE) in Catania (Italy), OGS in Trieste (Italy) and UTM-CSIC in Barcelona (Spain); in the latter location a specific simulation to opportunely model the source configuration was achieved using the GUNDALF array modeling software.

We planned to simultaneously acquire multibeam echosounder and sub bottom profiler data along the same routes of WAS and MCS lines of the R/V "Sarmiento de Gamboa" cruise, to gain further information about the seafloor features and the stratigraphy of the first tens of meters below, extending eastward the surveyed area investigated during previous oceanographic cruises [Chiocci et al. 2011].

The magnetic and gravity surveys (undertaken only in the Ionian Sea) were planned to identify any anomalies connected to the occurrence of volcanic features in front of Etna volcano [Del Negro and Napoli 2002; Patanè et al. 2009; Chiocci et al. 2011; Argnani et al. 2013]. A 250-300 m spaced grid of NE-SW oriented line-paths (Figure 3), was designed to transversely in- 
tersect the major volcano-tectonic features offshore Mt. Etna [Chiocci et al. 2011; Argnani et al. 2013]. Some other tie-lines were also scheduled along a NW-SE orientation to orthogonally cross the former ones to achieve a better control on data during the analysis phase. Within the planning of the H/V "Galatea" cruise, 3-4 full days were reserved for magnetic survey and 4 days (only in daytime) for ROV dives, while during the cruise extension, in 2015, about 7 full days were scheduled for the contemporaneous acquisition of magnetic and gravity data.

ROV dives were planned to directly explore some morpho-structures of high geological interest in shal- low water offshore Etna, which were detected during previous papers [Patanè et al. 2009; Chiocci et al. 2011], mainly taking into account the depth of the sites with respect to ROV operating depth (up to $300 \mathrm{~m}$ ) and distance from the coast (Figure 4).

The number of the scientific personnel on duty was organized according to the ships' accommodation and taking into account their practice and skill on data acquisition. Appropriate scientific teams from Spain (University of Granada) and Italy (INGV, OGS and University of Catania), including several degree students, were engaged.

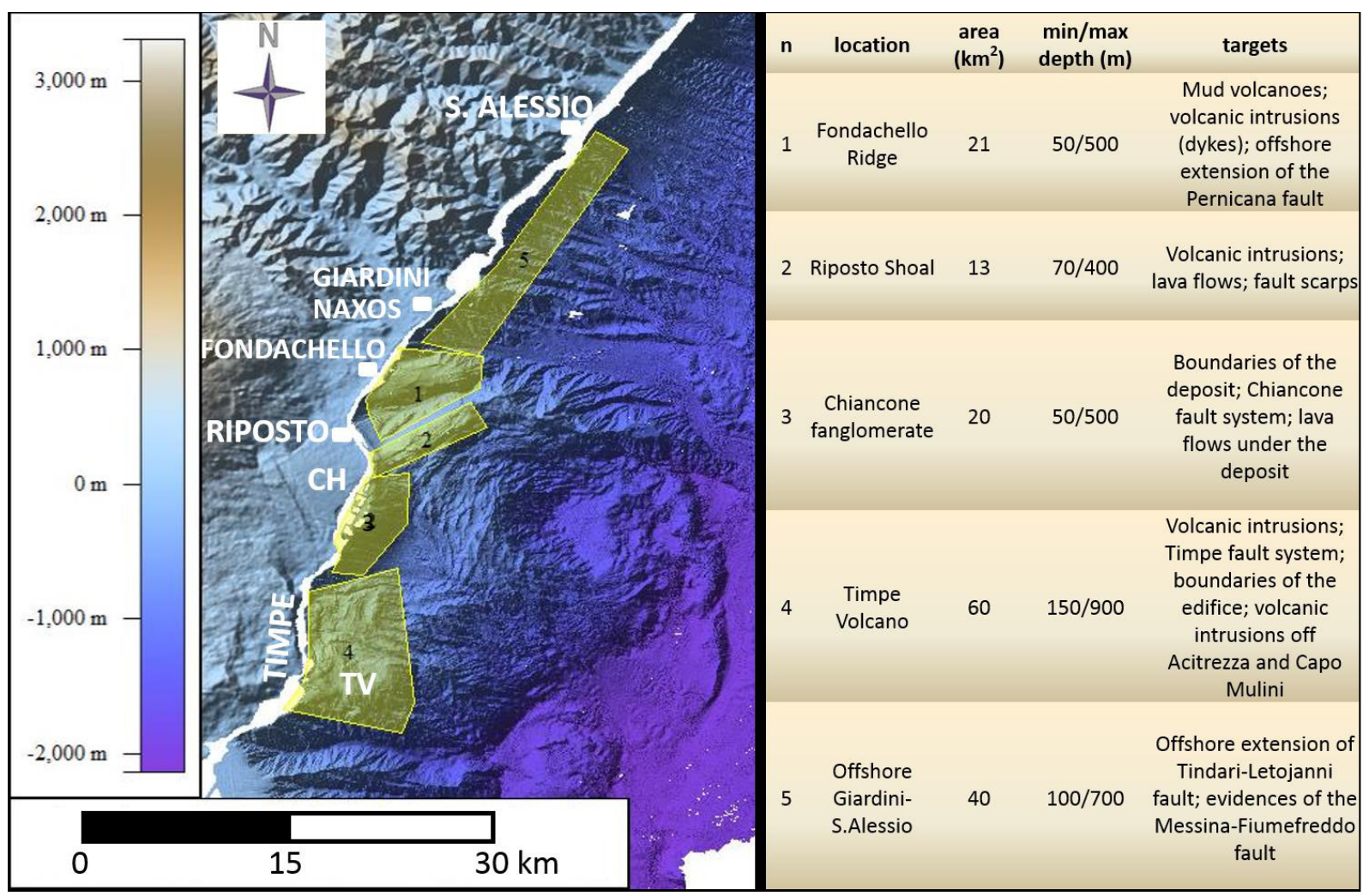

Figure 3. Planning of the magnetic and gravity surveys. $\mathrm{CH}$ (Chiancone deposit), TV (Timpe volcano).

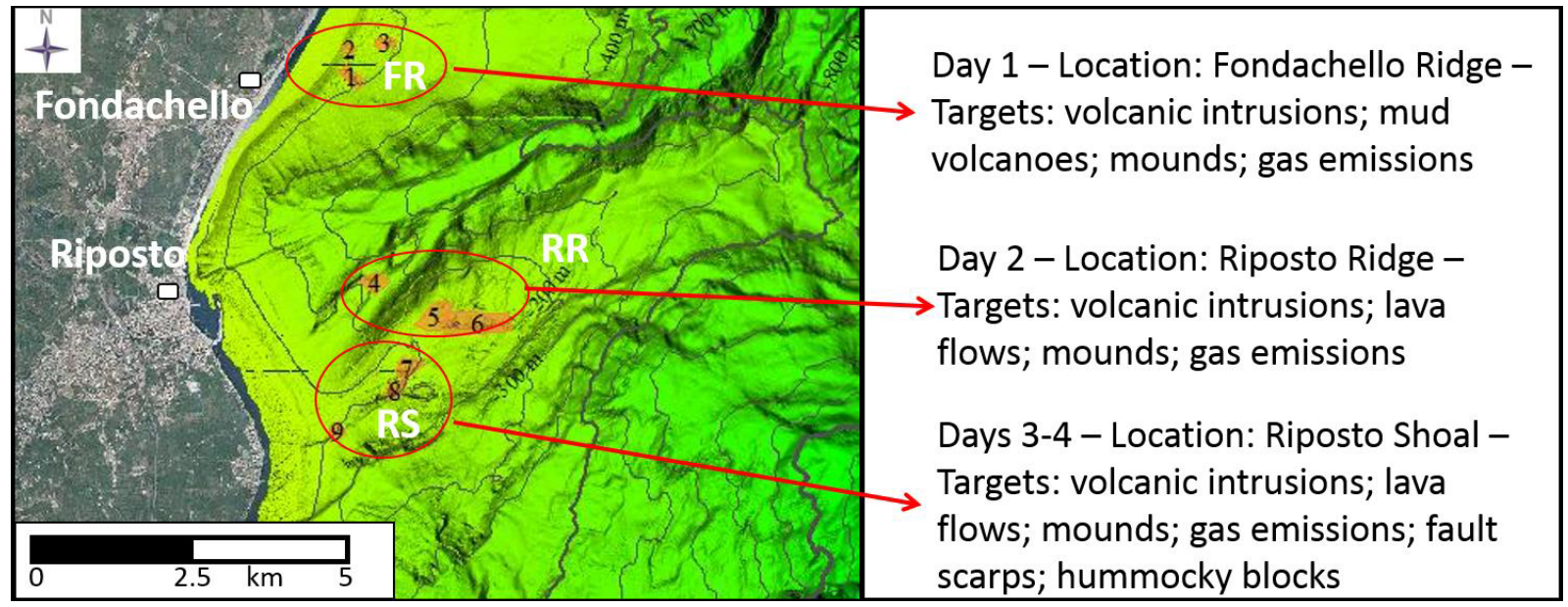

Figure 4. ROV dives planning on the shallow portion of the Riposto Ridge (RR). FR (Fondachello Ridge), RS (Riposto Shoal); contours every $100 \mathrm{~m}$. 


\subsection{Marine mammal safety monitoring}

The western Ionian Sea as well as the Aeolian Islands offshore includes many areas with critical habitats, where different cetacean species, such as the fin whale, are present all year round or travel during seasonal migrations. Seismic surveys produce anthropogenic noise that may interfere with natural functions of cetaceans, producing variable behavioral reactions. Effects from seismic survey activities need to be better understood to support mitigation measures to cetacean conservation and safeguard the entire marine environment. For these reasons, during the seismic activities on board the $\mathrm{R} / \mathrm{V}$ "Sarmiento de Gamboa", the plan was to engage a qualified marine biologist for marine mammal safety monitoring as well as to investigate effects of seismic air-gun activities on different species.

\section{Main characteristics of vessels}

Three research vessels ("Sarmiento de Gamboa", "Galatea", "Aegaeo"; Figure 5) belonging to different countries and institutions, were involved in the marine activities of the TOMO-ETNA experiment to collect geophysical data in both the Ionian and Tyrrhenian Seas. Table 1 shows their main specifications.

In addition, the patrol ship "Levanzo" by Italian Navy supported the R/V "Sarmiento de Gamboa" during the MCS survey.

\section{Technical equipment}

In this paragraph the scientific equipment employed during the three oceanographic cruises of the TOMO-ETNA experiment and their main technical specifications are described.

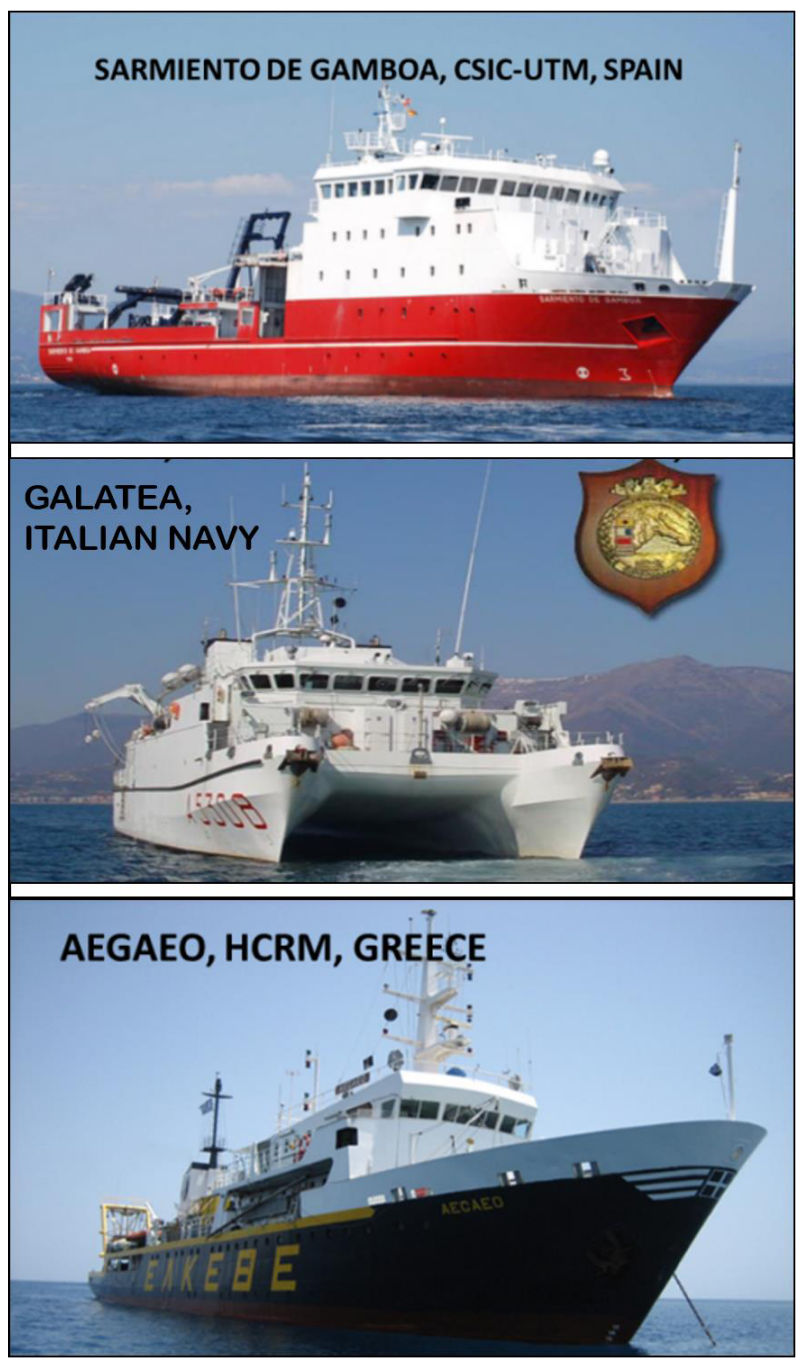

Figure 5. The three oceanographic vessels employed during the TOMO-ETNA experiment: R/V "Sarmiento de Gamboa" by CSICUTM (top), H/V "Galatea" by Italian Navy (middle) and R/V "Aegaeo" by HCR (bottom).

\begin{tabular}{lccc}
\hline & Sarmiento de Gamboa & Galatea & Aegaeo \\
\hline Type & Research vessel & $\begin{array}{c}\text { Hydro-oceanographic vessel } \\
\text { (catamaran) }\end{array}$ & Research vessel \\
\hline Owner/Operator & $\begin{array}{c}\text { CSIC-UTM } \\
\text { Consejo Superior } \\
\text { de Investigaciones Científicas - } \\
\text { Unidad de Tecnología Marina) } \\
\text { Spain }\end{array}$ & $\begin{array}{c}\text { Italian Navy, } \\
\text { Italy }\end{array}$ & $\begin{array}{c}\text { HCMR } \\
\text { (Hellenic Centre } \\
\text { for Marine Research) } \\
\text { Greece }\end{array}$ \\
\hline Year built & 2007 & 2000 & 1985 \\
\hline Length (m) & 70.50 & 39.2 & 61.51 \\
\hline Maximum breadth (m) & 15.50 & 12.60 & 9.60 \\
\hline Draft (m) & 4.6 & 2.5 & 2.9 \\
\hline Displacement (tons) & 850 & 415 & 778 \\
\hline Cruise speed (knots) & 15 & 13 & 12 \\
\hline Accommodation (crew + research) & $16+26$ & 31 & $18+22$ \\
\hline
\end{tabular}

Table 1. Main technical specifications of the oceanographic vessels employed during the TOMO-ETNA experiment. 


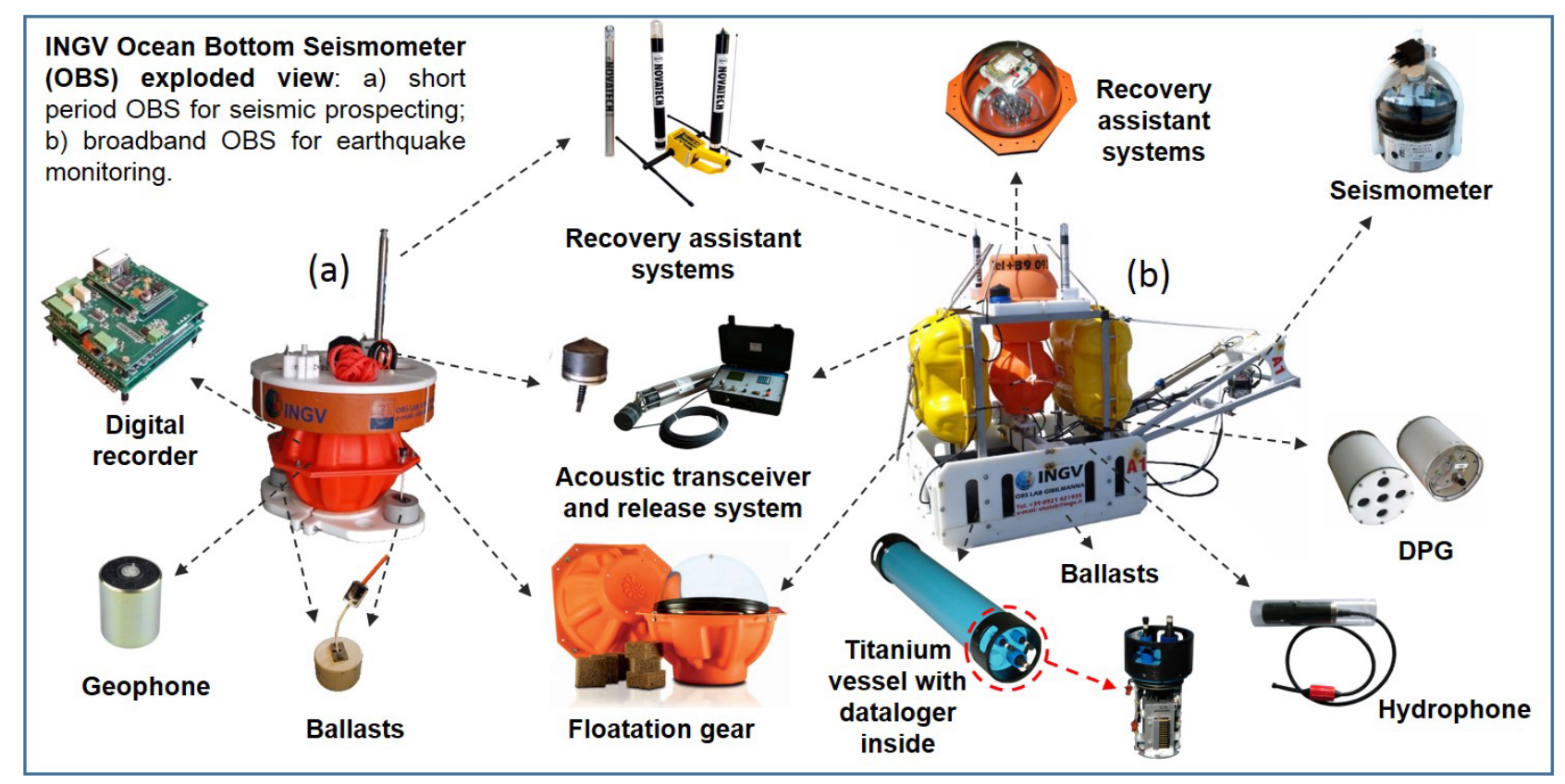

Figure 6. Two OBS types designed and built by INGV "OBS Lab" in Gibilmanna (Italy): (a) OBS SP equipped with a short-period sensor for seismic prospecting, (b) OBS/H BB equipped with a long-period sensor and hydrophone for both seismic prospecting and natural seismicity recording.

\subsection{OBS}

The OBSs employed during the TOMO-ETNA experiment consisted of 15 units of three-component shortperiod sensors with hydrophone $(\mathrm{OBS} / \mathrm{H})$ provided by UTM-CSIC, 2 units of three-component long-period sensors equipped with hydrophone (OBS/H BB) and 10 units of three-component short-period sensors (OBS SP) provided by INGV “OBS Lab” in Gibilmanna (Italy) (Figure 6). Table 2 shows the main technical specifications related to all types of OBSs deployed.

\subsection{WAS and MCS}

The main characteristics of the seismic equipment used for the MCS surveys with R/Vs "Sarmiento de Gamboa" and "Aegaeo" are reported in Table 3. Figure 7 shows the system for MCS acquisition on board the R/V "Aegaeo".

\subsection{Multibeam echosounder and sub bottom profiler}

The R/V "Sarmiento de Gamboa" was equipped with an acoustic "gondola" including multibeam (for shallow and deep waters), single beam (hydrographical) and parametric echosounder transducers (sub bottom profiler), installed on the lower surface, providing very high resolution seafloor mapping and penetration. This gondola is an "airplane-like" structure mounted on the hull, but separated from it, avoiding the bubbles produced by the bow of the ship that could affect the acoustic transducers installed on the lower surface. The instrument used for the bathymetric survey was an ATLAS Hydrosweep DS: a high-resolution multibeam echosounder suited for seabed mapping in deep water, with a sonar frequency between 14 to $16 \mathrm{kHz}$ (depth range: down to $11,000 \mathrm{~m} ; 320$ beams per ping). The sub bottom profile was an ATLAS Parasound 35 (depth range: to $11,000 \mathrm{~m}$; Max. bottom penetration $>150 \mathrm{~m}$; frequency bands: $18-33 \mathrm{kHz}$ high frequency and 0.5$6.0 \mathrm{kHz}$ parametric low frequency).

\subsection{Magnetometer}

To acquire the magnetic data on board the $\mathrm{H} / \mathrm{V}$ "Galatea”, a G880 geometrics magnetometer was provided by INGV (Figure 8). It is a marine caesium vapor pumped magnetometer used for high-resolution ship borne investigations. The magnetometer tow fish operated at about $1 \mathrm{~m}$ below the sea surface, but it is also suitable for deep-water investigation given its pressure rating of 2000 psi (approx. $1300 \mathrm{~m}$ ). G880 marine magnetometer has a $0.01 \mathrm{nT}$ of sensitivity at $1 \mathrm{~Hz}$ of sampling interval. It is suitable for worldwide application considering its operating range between 20,000 to $100,000 \mathrm{nT}$ and working temperatures ranging from $-35^{\circ}$ to $50^{\circ}$.

The tow fish is $7 \mathrm{~cm}$ diameter and $175 \mathrm{~cm}$ long for a total weight in air of about $12.5 \mathrm{~kg}$. It is towed by the stern of ships using a unique cable, which ensures communication and towing. Data output is provided by RS232 protocol at 9600 baud rates.

\subsection{Gravimeter}

The gravity survey on board the H/V "Galatea" was done using a Micro G LaCoste Air-Sea Gravity Sys- 


\begin{tabular}{|c|c|c|c|}
\hline \multicolumn{4}{|l|}{ Technical specifications of the OBSs } \\
\hline & OBS/H BB (ITA) & OBS SP (ITA) & OBS/H (SPA) \\
\hline Model & INGV BB-OBS/H & INGV OBS-SP & LC2000 SP $4 \times 4$ \\
\hline Dimensions $(\mathrm{cm})$ & $120 \times 80 \times 150$ & $60 \times 60 \times 70$ & $91 \times 66 \times 96$ \\
\hline Weight (kg) & 480 & 30 & 125 \\
\hline Seismic sensor & Guralp CMG40T-OBS & SM/ 6 GEOPHONE & Sercel L-28 \\
\hline $\begin{array}{l}\text { Frequency range } \\
\text { of the seismic sensor }(\mathrm{Hz})\end{array}$ & $1 / 60-100$ & $4.5-140$ & $4.5-1000$ \\
\hline Digitizer & Guralp CD24S4 & SeismoLog OBSLab & $\begin{array}{l}\text { Cirrus Logic Crystal } \\
\text { CS5321 Delta-Sigma }\end{array}$ \\
\hline Sampling rate (sample per second) & 100 & 250 & $1-4000$ \\
\hline Bit & 24 & 32 & 24 \\
\hline $\begin{array}{l}\text { Hydrophone/DPG } \\
\text { (differential pressure gauge) }\end{array}$ & $\begin{array}{c}\text { HighTechInc } \\
\text { HTI-04-PCA/ULF }\end{array}$ & / & HighTechInc HTI-90-U \\
\hline $\begin{array}{l}\text { Frequency range } \\
\text { of the Hydrophone/DPG }(\mathrm{Hz})\end{array}$ & $1 / 100-8000$ & / & $1 / 20-2500$ \\
\hline Battery packs & $\begin{array}{l}2 \text { primary lithium-thionyl } \\
\text { chloride battery packs } \\
\text { of } 14.4 \mathrm{~V} \text { and } 350 \mathrm{Ah}\end{array}$ & $\begin{array}{l}2 \text { alkaline } 9 \text { Volt } \\
\text { battery packs }\end{array}$ & $\begin{array}{c}1 \text { lithium battery pack } \\
\text { and } 2 \text { alkaline battery packs }\end{array}$ \\
\hline Release system & IXSEA mod. AR861S-MR & $\begin{array}{l}\text { IXSEA mod. AR9X1-OEM } \\
\text { or EDGETECH mod. C980172 }\end{array}$ & $\begin{array}{l}\text { Electrolytic system } \\
\text { IGPP-ORE offshore }\end{array}$ \\
\hline Ballast (kg) & 70 & 8 & 50 \\
\hline Autonomy (months) & $\begin{array}{l}12-24 \text { (depending from } \\
\text { the installed instrumentations) }\end{array}$ & $4-6$ & $8-9$ \\
\hline Localization system & $\begin{array}{c}\text { GPS receiver } \\
\text { integrated with a sat-phone } \\
\text { transmitting the position } \\
\text { every 3-6 hours } \\
\text { when OBS is floating, } \\
\text { radio beacon, } \\
\text { intermittent light and flag }\end{array}$ & Intermittent light and flag & $\begin{array}{l}\text { Intermittent light } \\
\text { Novatech ST-400A, } \\
\text { radio Beacon Novatech } \\
\text { RF-700A1 and flag }\end{array}$ \\
\hline
\end{tabular}

Table 2. Main technical specifications of the OBSs employed during the three oceanographic cruises of the TOMO-ETNA experiment.

tem II. ENI SpA is the owner of this special instrument, currently managed and used for scientific purpose by the Geophysics and Marine Technologies unit of INGV at La Spezia, according to a loan agreement between ENI and INGV signed in 2013. The Air-Sea Gravity System II is characterized by a recording sensor associated to a gyro-stabilized system controlled by two torque motors to maintain the stabilized vertical. Two feedback loops for each torque motor are employed. The gyroscopes (torque motors) are coupled to two accelerometers for a strong feedback on the verticality. Pitch and roll movements of the vector are minimized by the gyro-accelerometers system. Vertical accelerations are partially absorbed by air-shock mounts, but not completely removed. The main specifications of this instrumentation are reported in Table 4.

\section{6. $R O V$}

The ROV dives campaign was carried out directly from H/V "Galatea” by using a ROV Sirio by Ageotec (operating depth of $300 \mathrm{~m}$ ), belonging to the ROV "Observer Class” for visual inspections (Figure 9). ROV was provided by INGV; its main specifications are reported in Table 5. 


\begin{tabular}{|c|c|c|}
\hline \multicolumn{3}{|l|}{ Seismic equipment } \\
\hline & R/V Sarmiento de Gamboa & R/V Aegaeo \\
\hline Seismic air-gun controllers & Big shot by Real time system & RTS Sure Shot \\
\hline Navigation and triggering system & Eiva & Teledyne Reson - PDS2000 \\
\hline MCS acquisition system & SEAL 408XL & CNT2 Geometrics software running on PC \\
\hline Quality control system & ESQC-Pr & CNT 2 Marine controller \\
\hline \multicolumn{3}{|l|}{ Seismic sources } \\
\hline Gun model and array & Two parallel arrays of eight Sercel G-GUN II & One Sercel GI-GUN + one Sercel Mini GI-GUN \\
\hline Total volume (cu. in./l) & $5200 / 85.21$ (WAS) - $4340 / 71.12$ (MCS) & $270 / 4.43$ \\
\hline Air pressure (bar) & 140 & 140 \\
\hline Depth (m) & 15 (WAS) - 7.5 (MCS) & 2 \\
\hline Shot interval & $90 \mathrm{~s}$ (WAS) - $37.5 \mathrm{~m}$ (MCS) & $21.875 \mathrm{~m}$ \\
\hline \multicolumn{3}{|l|}{ Receiver system } \\
\hline Streamer model & Sercel-Sentinel & Geometrics - GeoEel \\
\hline Length of active section (m) & 3000 & 300 \\
\hline Total length (m) & 3550.24 & 328.12 \\
\hline Channels & 240 & 96 \\
\hline Hydrophones for each channel & 8 & 4 \\
\hline Channel distance $(\mathrm{m})$ & 12.5 & 3.125 \\
\hline Streamer depth (m) & 10 & 1.5 \\
\hline Sample rate $(\mathrm{ms})$ & 2 & 1 \\
\hline Tail buoy & Buoylink by SEAMAP & Standard floating \\
\hline Birds & Nautilus-Sercel and Digicorse-ION & Digicourse Digibird 5010 \\
\hline Compass/airbags & OyoGeospace & I/O Model 587 \\
\hline
\end{tabular}

Table 3. Main characteristics of the seismic equipment used for the WAS and MCS surveys of the TOMO-ETNA experiment.

The ROV was preliminary arranged with a manipulator (with two different possible motions: updown and left-right) to collect seafloor samples. If necessary, the manipulator could be replaced by a small grab sampler to collect some sediment from the sea bottom (Figure 10). Moreover, a specific gas sampler was set up on the manipulator for this campaign by researchers of the INGV Section of Palermo, to eventually collect gas bubbles released from fumarole fields for achieving important geochemistry analysis. To check the asset of the ROV during the gas sampling operations an appropriate test was performed before beginning the cruise. In case of use of the gas sampler, the ROV chassis was made ready for arranging some slices of polyurethane foam to ensure the neutral asset of the ROV. In fact, even if the weight of the gas sampler was largely within the ROV payload $(8 \mathrm{~kg})$, its collocation on the lateral side of the chassis could compromise the hydrostatic balance and then the ROV navigation.

\section{Organization of scientific activities on board}

5.1. Embarkation and disembarkation of the oceanographic cruises

The cruise on board the R/V "Sarmiento de Gamboa" started from Messina on June 24 and ended in Catania on July 20, 2014. It was divided into 2 legs with a halfway stop (on July 6) in Stromboli Island to allow the CSIC-UTM technicians to change the airguns configuration for switching from WAS to MCS survey.

The first cruise on the H/V "Galatea" started on June 25 from Messina military harbor and ended on July 3, 2014, at the same port; while the second cruise started on June 17 from Augusta military harbor and ended on June 23, 2015, at the same port.

The cruise on board the R/V "Aegaeo" took place on November 19, 2014, departing from Catania port and arriving back at the same harbor on November 26, 2014, without any stops in between. 


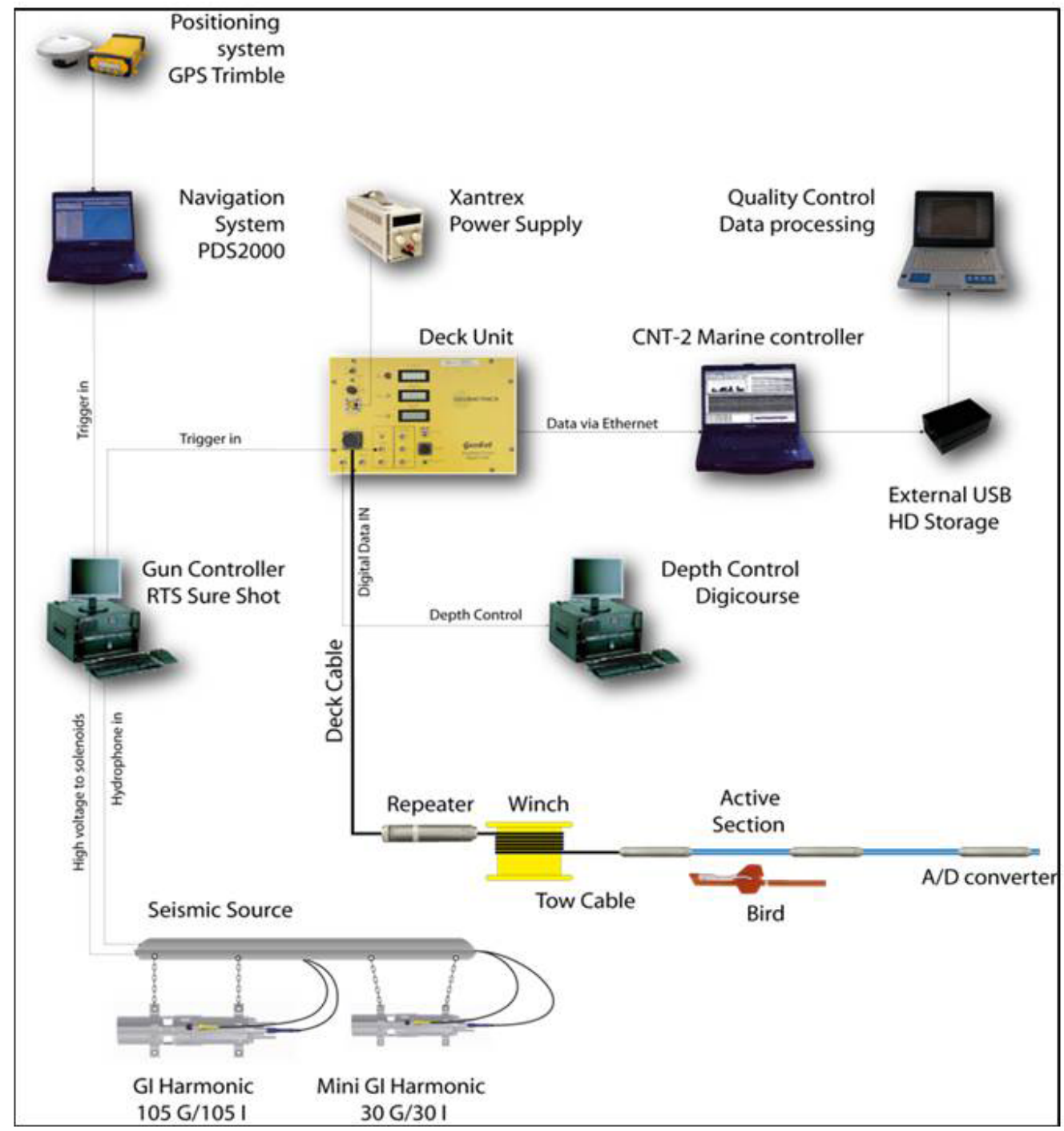

Figure 7. Block diagram illustrating the system for MCS acquisition set on board the R/V "Aegaeo".

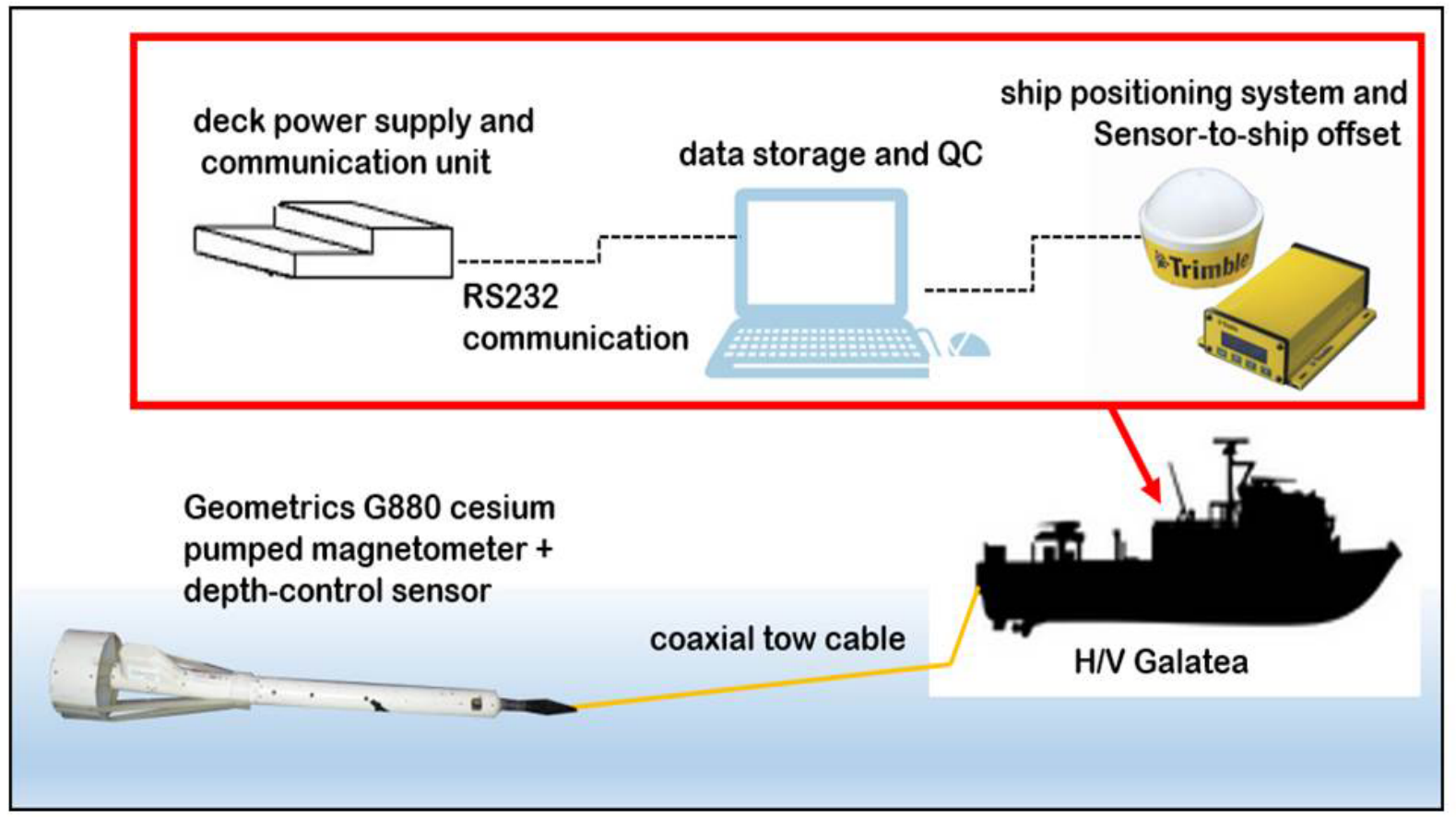

Figure 8. Block diagram illustrating the magnetic system used on board the H/V "Galatea". 
Technical specifications

of the Micro G LaCoste Air-Sea Gravity System II

\begin{tabular}{lc}
\hline Range (Mgal) & 20,000 \\
\hline Drift (Mgal/month) & 3 \\
\hline Recording rate (Hz) & 1 \\
\hline Resolution (Mgal) & 0.01 \\
\hline Accuracy at sea (Mgal) & $<1.00$ \\
\hline Dimensions (cm) & $71 \times 56 \times 84$ \\
\hline Weight $(\mathrm{kg})$ & 86 \\
\hline
\end{tabular}

Table 4. Main technical specifications of the gravimeter used during the oceanographic cruise on the H/V "Galatea".

On June 24, 2014, in Messina Italian Navy headquarters, the marine campaign of TOMO-ETNA experiment officially started with a press conference. The conference was presided by the highest authorities of the naval base of Messina, the commander of the H/V "Galatea" (Italian Navy), the captain of the Spanish R/V "Sarmiento de Gamboa” (CSIC-UTM) and by two of the coordinators of the experiment, Dr. D. Patanè of INGV-OE, Catania (Italy), and Prof. J.M. Ibáñez from the University of Granada (Spain), during which the main objectives and expected results of

\begin{tabular}{ll}
\hline \multicolumn{2}{l}{ Technical specifications of the ROV Sirio } \\
\hline Class & Observer \\
\hline Operating depth $(\mathrm{m})$ & 300 \\
\hline Dimensions $(\mathrm{cm})$ & $59 \times 56 \times 45$ \\
\hline Weight $(\mathrm{kg})$ & 40 \\
\hline Chassis & $\begin{array}{l}\text { High impact resistant } \\
\text { maintenance free polyethylene }\end{array}$ \\
\hline Cameras & No. 1 color \\
\hline Power requirements & $\begin{array}{l}220-240 \text { VAC, } 380-410 \mathrm{VAC} \\
\text { single phase } 50 / 60 \mathrm{~Hz} 3 \mathrm{~kW}\end{array}$ \\
\hline Payload & $\begin{array}{l}8 \mathrm{~kg} \text { (up to } 10 \mathrm{~kg} \\
\text { with optional buoyancy) }\end{array}$ \\
\hline Umbilical length $(\mathrm{m})$ & 250 \\
\hline
\end{tabular}

Table 5. Main technical specifications of the ROV used during the $\mathrm{H} / \mathrm{V}$ "Galatea" cruise.

the experiment were described (see also Ibáñez et al. [2016a] in this volume). Moreover, the Commander of the H/V "Galatea" and Captain of the R/V "Sarmiento de Gamboa" discussed about coordinating the scientific activities of the respective vessels, the two cruises being overlapped in time.

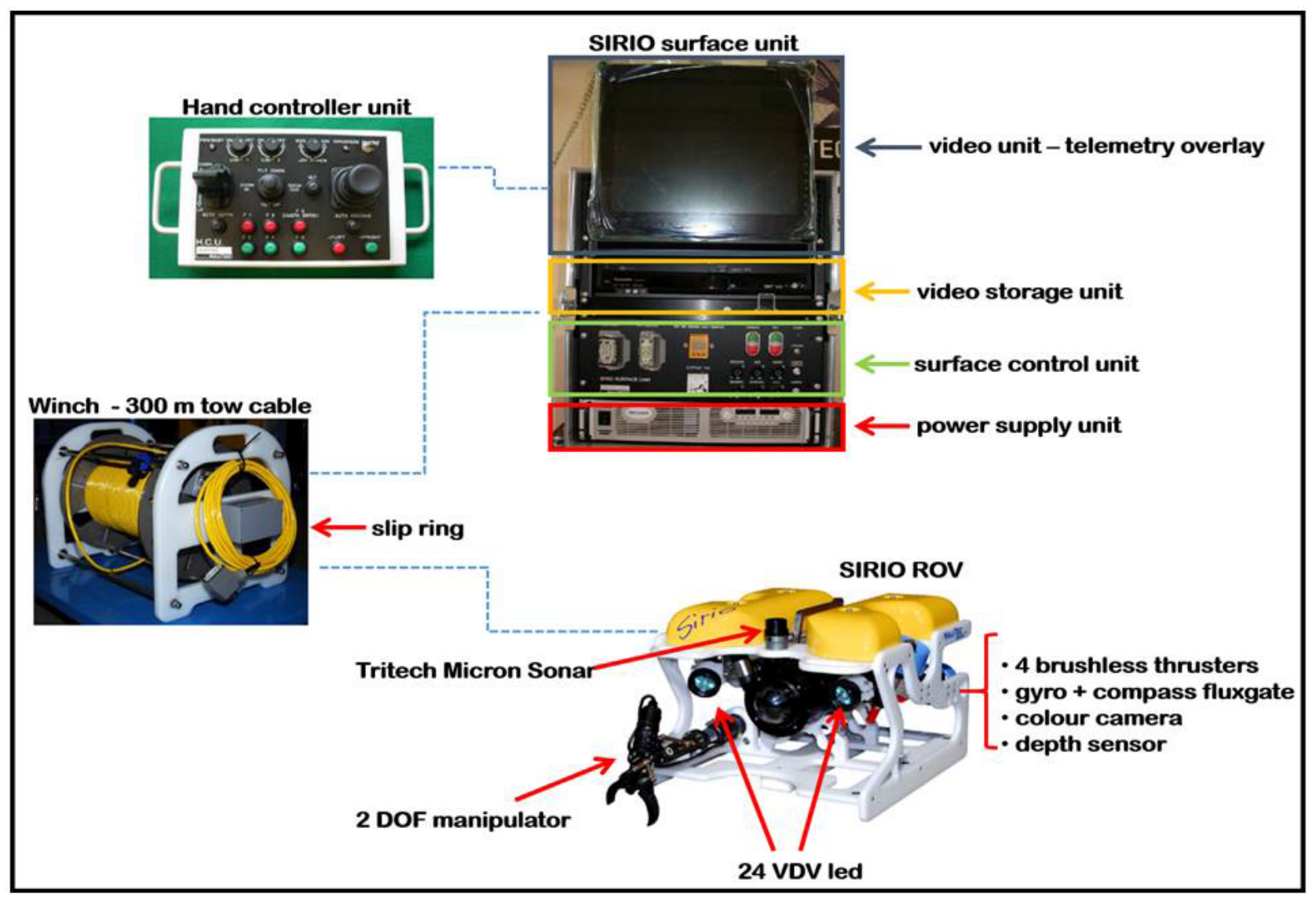

Figure 9. Block diagram of the Sirio ROV with its control and recording system. 


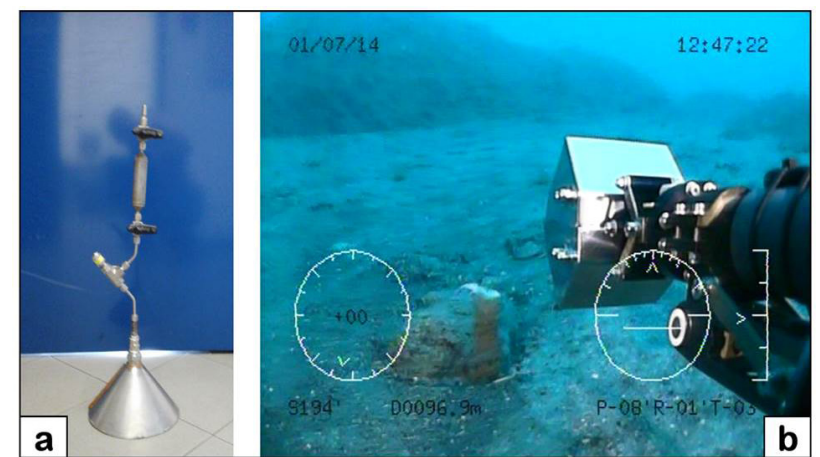

Figure 10. The gas sampler of the ROV to collect gas bubbles eventually released from seabed (a) and the sampler grab to collect sediment from the sea bottom (b).

\subsection{Scientist teams organization during the cruises:} shifts for data acquisition

The science parties for the cruises consisted in qualified scientists and students belonging to different institutions. Data acquisition and quality control (QC) was assigned to ship technicians (belonging to CSIC, INGV, OGS, HCMR and Italian Navy) and to experienced personnel of the scientific teams, whereas students were mostly employed for checking the navigation and the continuity of data acquisition, as well as for drafting the cruise narrative, in the framework of their on-field training stage. Concerning the R/Vs "Sarmiento de Gamboa" (Figure 11) and "Aegaeo" cruises, three teams of 4 scientists-students were on duty for each round, consisting in 4 hours of service twice a day. For the H/V "Galatea" cruise the scientific team was a little short-handed, thus no fixed shifts were done. A fundamental help was given by the ship's crewmembers in assisting during the surveys. All the science parties employed in the TOMOETNA cruises are listed in the following Tables 6-8.

\subsection{Scientific seminars on board the $R / V$ "Sarmiento} de Gamboa"

Several scientific seminars were held on board the R/V "Sarmiento de Gamboa” during the oceanographic cruise to integrate the on-field training stage of the students, as also suggested by EUROFLEETS practices. The seminars were organized in seven sessions and carried out, mostly during the transfer phases between acquisition surveys. During the meetings, several topics, concerning marine mammals biology, geology, geophysics and volcanology, were presented and discussed. The speakers (professors, senior scientists and PhD students), belonging to different countries and institutions, were part of the scientific team on board. The seminars were focused to enrich the scientific knowledge of participants and to acquire a more advanced mastery in geophysical data acquisition and QC, also useful for the experienced personnel. In Table 9 the seminars carried out on board the R/V "Sarmiento de Gamboa” are reported.

\subsection{The $R / V$ "Sarmiento de Gamboa" cruise narrative}

The cruise narrative on board the R/V "Sarmiento de Gamboa”, written by M.E. Claude with the support of the Prof. F. Carrión, and translated into three

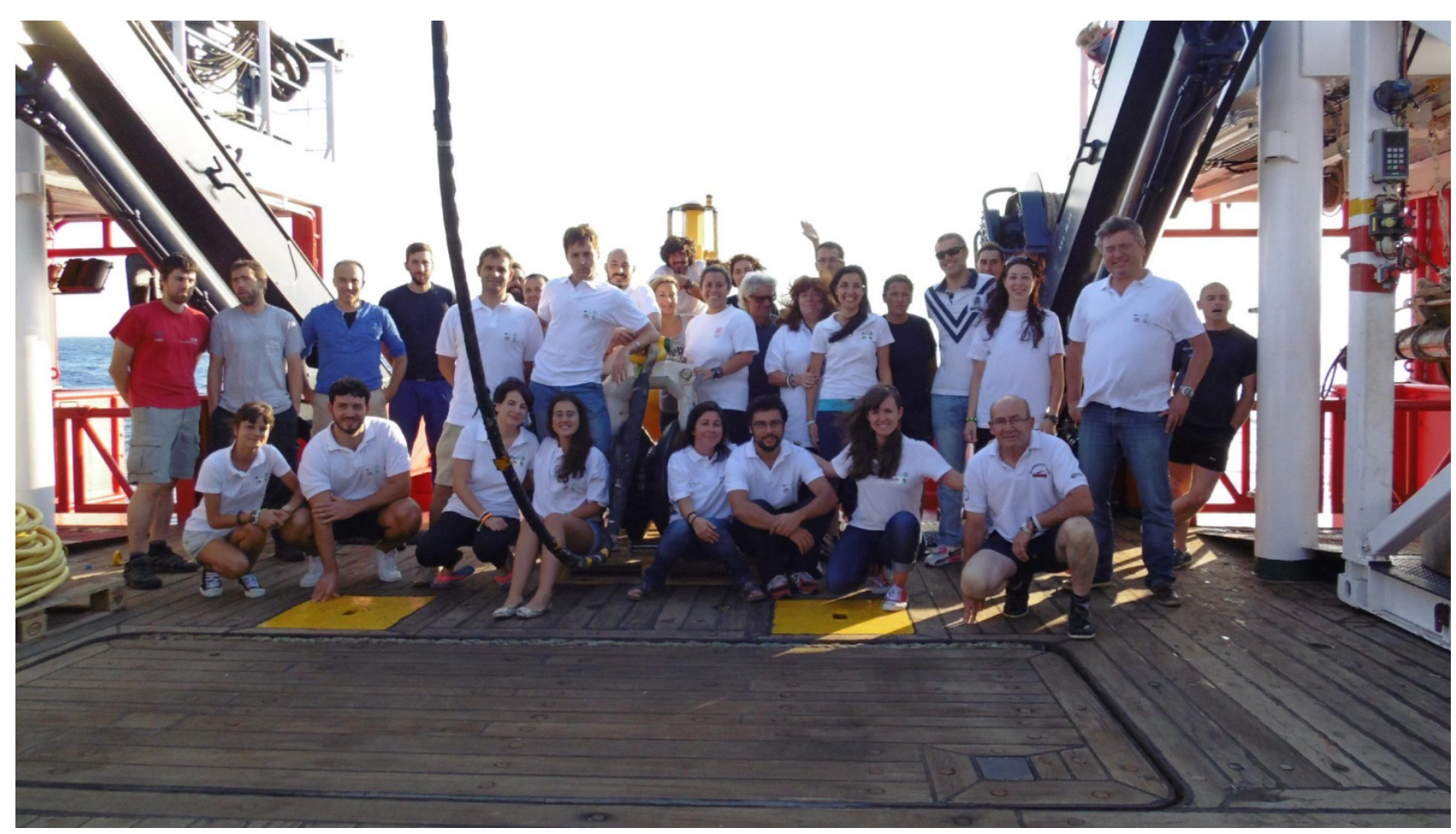

Figure 11. The scientific team with some of the crew members and technicians on board the R/V "Sarmiento de Gamboa". 
COLTELLI ET AL.

\begin{tabular}{|c|c|c|}
\hline Name & Position & Institute \\
\hline Francisco Carrión & Chief scientist (I LEG) & University of Granada \\
\hline Mauro Coltelli & Chief scientist (II LEG) & INGV-OE \\
\hline Teresa Teixidó & Data acquisition - QC & University of Granada \\
\hline Mayte Pedrosa & Data acquisition - QC & University of Granada \\
\hline Danilo Cavallaro & Data acquisition - QC & University of Catania - INGV-OE \\
\hline Marco Firetto Carlino & Data acquisition - QC & INGV-OE \\
\hline Clara Monaco & Marine biologist & University of Catania \\
\hline Fabrizio Cultrera & Surveyor & University of Catania \\
\hline Eloisa Claude & Surveyor & INGV-OE \\
\hline Diego Martín Jiménez & Surveyor & University of Granada \\
\hline Ana Isabel Lozano & Surveyor & University of Granada \\
\hline Judit González & Surveyor & University of Granada \\
\hline José Manuel Muñoz Hermosilla & Surveyor & University of Granada \\
\hline Nuria Gutiérrez Luna & Surveyor & University of Granada \\
\hline Elsa María Alfonso Sánchez & Surveyor & University of Granada \\
\hline
\end{tabular}

Table 6. The scientific team on board the R/V "Sarmiento de Gamboa".

\begin{tabular}{lll}
\hline Name & Position & Institute \\
\hline Giuseppe D’Anna & OBS surveyor & INGV-CNT \\
\hline Giuseppe Passafiume & OBS technician & INGV-CNT \\
\hline Gioacchino Fertitta & OBS technician & INGV-CNT \\
\hline Danilo Cavallaro & ROV surveyor & University of Catania - INGV-OE \\
\hline Luca Cocchi` & Magnetic and gravity surveyor & INGV-Roma2 \\
\hline Filippo Muccini & Magnetic surveyor & INGV-Roma2 \\
\hline Fausto Grassa & ROV surveyor & INGV-PA \\
\hline Daniele Dell'Anna & ROV technician & Subonica \\
\hline
\end{tabular}

Table 7. The scientific team on board the H/V "Galatea" (*personnel that participate in both 2014 and 2015 cruises).

\begin{tabular}{lll}
\hline Name & Position & Institute \\
\hline Mauro Coltelli & Chief scientist & INGV-OE \\
\hline Marco Firetto Carlino & Surveyor & INGV-OE \\
\hline Salvatore Rapisarda & Technician & INGV-OE \\
\hline Giuseppe Passafiume & Technician & INGV-CNT \\
\hline Danilo Cavallaro & Surveyor & University of Catania - INGV-OE \\
\hline Fabrizio Cultrera & Surveyor & University of Catania \\
\hline Fabrizio Zgur & Data acquisition - QC & OGS (Trieste) \\
\hline Lorenzo Facchin & Data acquisition - QC & OGS (Trieste) \\
\hline Lorenzo Sormani & Data acquisition - QC & OGS (Trieste) \\
\hline Giampaolo Visnovic & Technician (gun mechanic) & OGS (Trieste) \\
\hline Paolo Mansutti & Technician (gun mechanic) & OGS (Trieste) \\
\hline Diego Cotterle & Technician (gun mechanic) & OGS (Trieste) \\
\hline Rita Blanos & Surveyor & OGS (Trieste) \\
\hline Aristomenis P. Karageorgis & Marine geologist & HCMR (Greece) \\
\hline
\end{tabular}

Table 8. The scientific team on board the R/V "Aegaeo". 


\begin{tabular}{lll}
\hline Date & Speakers & Title \\
\hline June 26 & Clara Monaco & $\begin{array}{l}\text { Cetaceans: recognition, their distribution and data collection. Geoseismic prospecting: effects on cetaceans } \\
\text { and mitigation measures }\end{array}$ \\
\hline June 30 & Mauro Coltelli & Etna Volcano: from geological history up to the present-day eruptions monitoring \\
\hline July 2 & Mauro Coltelli & $\begin{array}{l}\text { The sliding of Etna eastern flank from land to sea and back to land, how a large-scale regional instability } \\
\text { controls the life of an active volcano }\end{array}$ \\
\hline July 9 & Mauro Coltelli & History and main geological features of Stromboli volcano \\
\hline July 9 & Teresa Teixidó & De que va la tomografia sísmica y sísmica de reflexion \\
\hline July 14 & Mayte Pedrosa & Main continental shelf slope seabed morphologies \\
\hline July 15 & Teresa Teixidó & A nosotros nos lo miran \\
\hline July 18 & Fabrizio Cultrera & Geodynamic framework of Southern Tyrrhenian Sea and implications for active tectonics \\
\hline
\end{tabular}

Table 9. The scientific seminars on board the R/V "Sarmiento de Gamboa".

languages (Italian, Spanish and English), is available on the website of the University of Granada at the following link http:/ / iagpds.ugr.es/pages/proyecto_italia/diario. It represents a technical report in which all the research activities and management work, carried out on board the R/V "Sarmiento de Gamboa", were described chronologically and in detail. Every day, meteorological observations, survey routes, technical and scientific activities and all events related to navigation (including technical issues), were noted, indicating the start and end time (Figure 12). The route maps, including coordinates of the start and end of lines, were annexed in auxiliary tables. The documentation was enhanced with photos and figures of the equipment, scientific and technical team and crew during working activities. The draft of cruise narrative was made possible by the interaction with the CSIC-UTM technicians and the members of the scientific team, also correlating the technical forms compiled in acoustic and seismic control rooms of the ship.

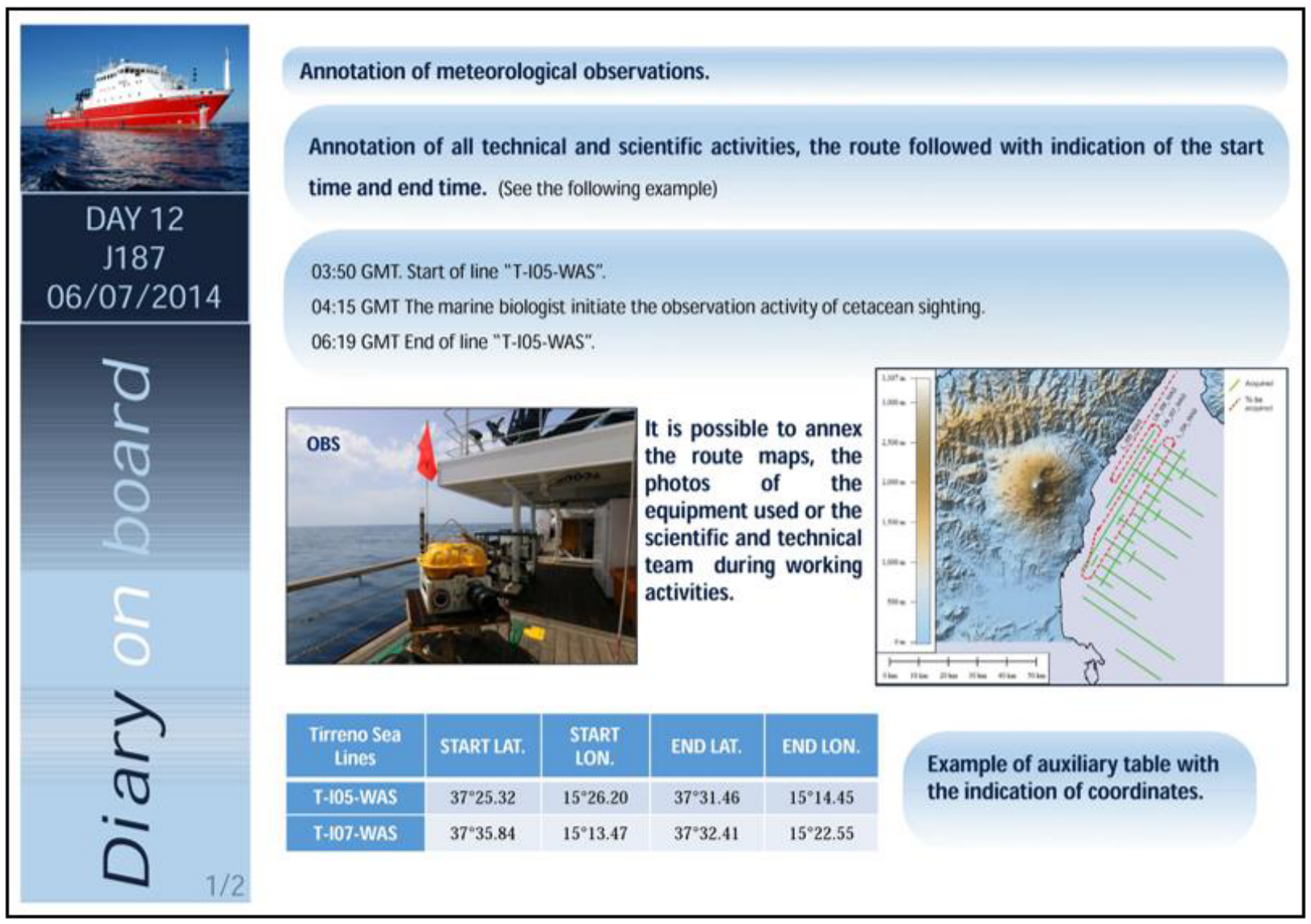

Figure 12. Example of a page of the cruise narrative that illustrates the scientific activity on board the R/V "Sarmiento de Gamboa". 


\begin{tabular}{lcl}
\hline Day $(\mathrm{dd} / \mathrm{mm} /$ yyyy) & LEG & Scientific activity \\
\hline $24 / 06 / 2014-27 / 06 / 2014$ & I & OBS deployment \\
\hline $27 / 06 / 2014-02 / 07 / 2014$ & I & WAS and bathymetric survey - Ionian Sea \\
\hline $02 / 07 / 2014-06 / 07 / 2014$ & I & WAS and bathymetric survey - Tyrrhenian Sea \\
\hline $07 / 07 / 2014-08 / 07 / 2014$ & II & Bathymetric survey around Stromboli Island \\
\hline $08 / 07 / 2014-10 / 07 / 2014$ & II & WAS and bathymetric survey - Tyrrhenian Sea \\
\hline $11 / 07 / 2014-17 / 07 / 2014$ & II & MCS and bathymetric survey - Ionian Sea \\
\hline $17 / 07 / 2014-20 / 07 / 2014$ & II & OBS recovery \\
\hline
\end{tabular}

Table 10. The scientific activity on board the R/V "Sarmiento de Gamboa".

At the end of the oceanographic cruises a scientific report (containing also the narrative cruise) was drafted and published on the following websites:

- http: / / iagpds.ugr.es/pages/proyecto_italia/documen tos /_doc/middletermexperimenttomoetna1/

- http: / / iagpds.ugr.es/pages/proyecto_italia/documen tos/_doc/endexperimentphase1/

- http: / /iagpds.ugr.es/pages/proyecto_italia/documen tos/_doc/deliverable54final/

- http: / /iagpds.ugr.es/pages/proyecto_italia/documen tos/_doc/report_aegaeo/.

The first three links are related to the first phase of the experiment carried out on board the vessels "Sarmiento de Gamboa" and "Galatea", while the fourth is related to the second phase performed on board the R/V "Aegaeo".

\subsection{Marine mammal watching activity}

Marine mammal monitoring, on board the R/V "Sarmiento de Gamboa", was conducted by a qualified marine biologist (hereafter: First observer), experienced

\begin{tabular}{ll}
\hline Day $(\mathrm{dd} / \mathrm{mm} /$ yyyy $)$ & Scientific activity \\
\hline $25 / 06 / 2014-26 / 06 / 2014$ & OBS deployment \\
\hline $27 / 06 / 2014$ & Magnetic survey \\
\hline $28 / 06 / 2014-01 / 07 / 2014$ & ROV dives - Magnetic survey \\
\hline $02 / 07 / 2014-03 / 07 / 2014$ & Magnetic survey \\
\hline $17 / 06 / 2015-23 / 07 / 2015$ & Magnetic and gravity surveys \\
\hline
\end{tabular}

Table 11. The scientific activity on board the H/V "Galatea".

\begin{tabular}{ll}
\hline Day $(\mathrm{dd} / \mathrm{mm} /$ yyyy $)$ & Scientific activity \\
\hline $20 / 11 / 2014-25 / 11 / 2014$ & MCS - Tyrrhenian Sea \\
\hline $25 / 11 / 2014-26 / 11 / 2014$ & OBS recovery \\
\hline $26 / 11 / 2014$ & MCS - Ionian Sea \\
\hline
\end{tabular}

Table 12. The scientific activity on board the R/V "Aegaeo". in conducting sea surveys and able to identify cetacean species and define their behavioral patterns [Monaco et al. 2016, in this volume]. The Chief scientists of the cruise acted as marine mammal monitoring coordinator during seismic surveying activities. They supervised the scientific team on board, assisting it in the distribution of information and making a connection between marine mammals observers on the bridge deck and technicians in the control room.

Before the start of seismic activities, the First observer gave some lessons and instructions to the scientific and technic personnel to show how to apply the Joint Nature Conservation Committee (JNCC) protocol guidelines, to identify marine mammal species and collect sighting data. These trained marine mammal observers supported the First observer in visual monitoring with shifts of about one hour, when possible.

Marine mammal watching activities were conducted only in daytime, during both seismic activities with airguns on and other activities with air-guns off. For more information about the marine mammal monitoring on board the R/V "Sarmiento de Gamboa" see Monaco et al. [2016, in this volume].

\section{Scientific activities and data acquisition}

The following Tables 10-12 show the scientific activities performed in each oceanographic vessel during the TOMO-ETNA experiment.

All data acquired on board the three oceanographic vessels were obtained using the navigation parameters reported on Table 13.

\subsection{OBS}

A total of 27 OBSs were employed during the TOMO-ETNA experiment: 22 were deployed in the Ionian Sea and 5 in the Tyrrhenian Sea, to record either the natural seismicity and the seismic signals generated by the air-gun arrays during the R/V "Sarmiento de Gamboa” cruise (Figures 13 and 14). 15 OBS/ Hs (shortperiod seismometer with hydrophone, model LC2000 


\begin{tabular}{|c|c|c|}
\hline \multirow{4}{*}{ Acquisition and target datum } & \multicolumn{2}{|l|}{ WGS84 } \\
\hline & Spheroid & WGS84 \\
\hline & Semiaxis major & 6378137 \\
\hline & Inverse flattening & 298.25722356 \\
\hline \multirow[t]{4}{*}{ Datum transformation } & \multicolumn{2}{|l|}{ Null } \\
\hline & \multicolumn{2}{|c|}{ Universal transverse mercator (UTM) } \\
\hline & Zone & $33 \mathrm{~N}(15 \mathrm{E})$ \\
\hline & Origin latitude & $00^{\circ} 00^{\prime} 00^{\prime \prime} \mathrm{N}$ - Equator \\
\hline \multirow[t]{4}{*}{ Projection } & Central meridian & $015^{\circ} 00^{\prime} 00^{\prime \prime} \mathrm{E}$ \\
\hline & False northing & $0.00 \mathrm{~m}$ \\
\hline & False easting & $500,000 \mathrm{~m}$ \\
\hline & Scale factor & 0.999600 \\
\hline
\end{tabular}

Table 13. The navigation parameters adopted during the marine activities of the TOMO-ETNA experiment.

SP $4 \times 4$ ) were positioned by the R/V "Sarmiento de Gamboa" in the Ionian Sea, while 10 OBSs SP (shortperiod seismometer) and 2 OBS/Hs BB (broadband seismometer with hydrophone) by the H/V "Galatea" in both the Ionian and Tyrrhenian Seas. Before the OBSs dropping, an acoustic transponder tests, called "rosette test" (Figure 13), was performed near to the deepest OBS planned site to verify the correct functioning, during the recovering phase, of the acoustic transponders installed inside each OBS.

The rather complex and time-consuming deploy-
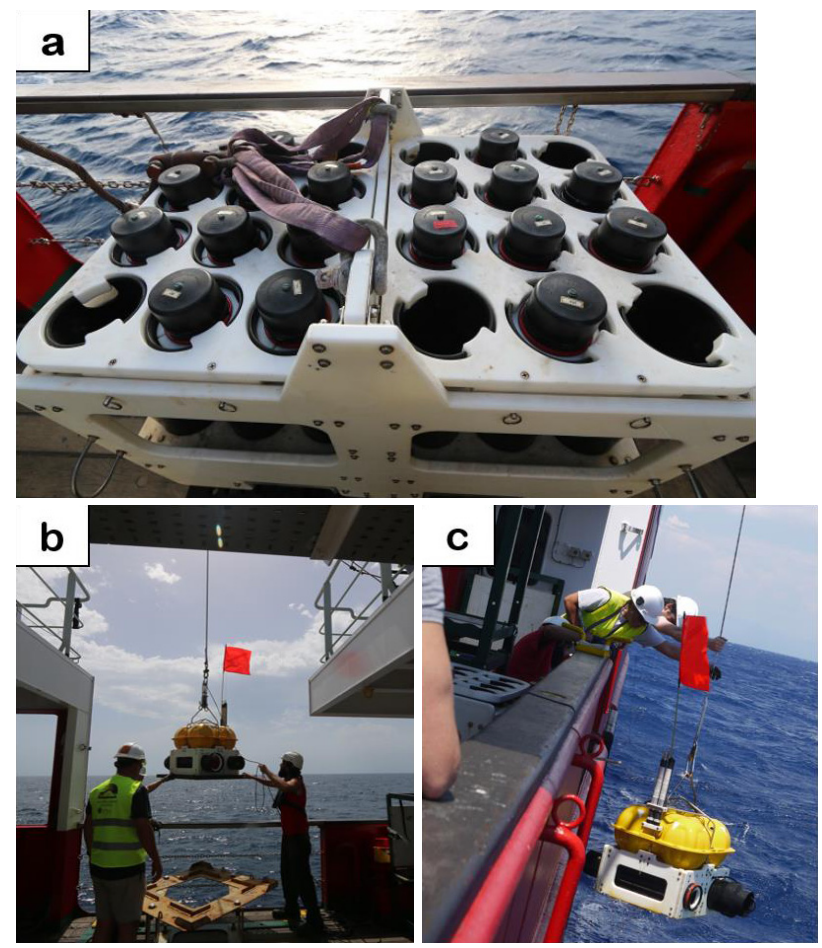

Figure 13. Rosette test (a), OBS deploying (b) and recovering (c) phases on board the R/V "Sarmiento de Gamboa". ing procedure entails: (a) reaching the selected position and stopping the vessel; (b) preparing the OBS and dropping it in the water; (c) waiting till the OBS reaches the sea bottom following its descent through an acoustic ranging system; (d) disabling the acoustic transponder once the OBS reaches the bottom; (e) moving the vessel

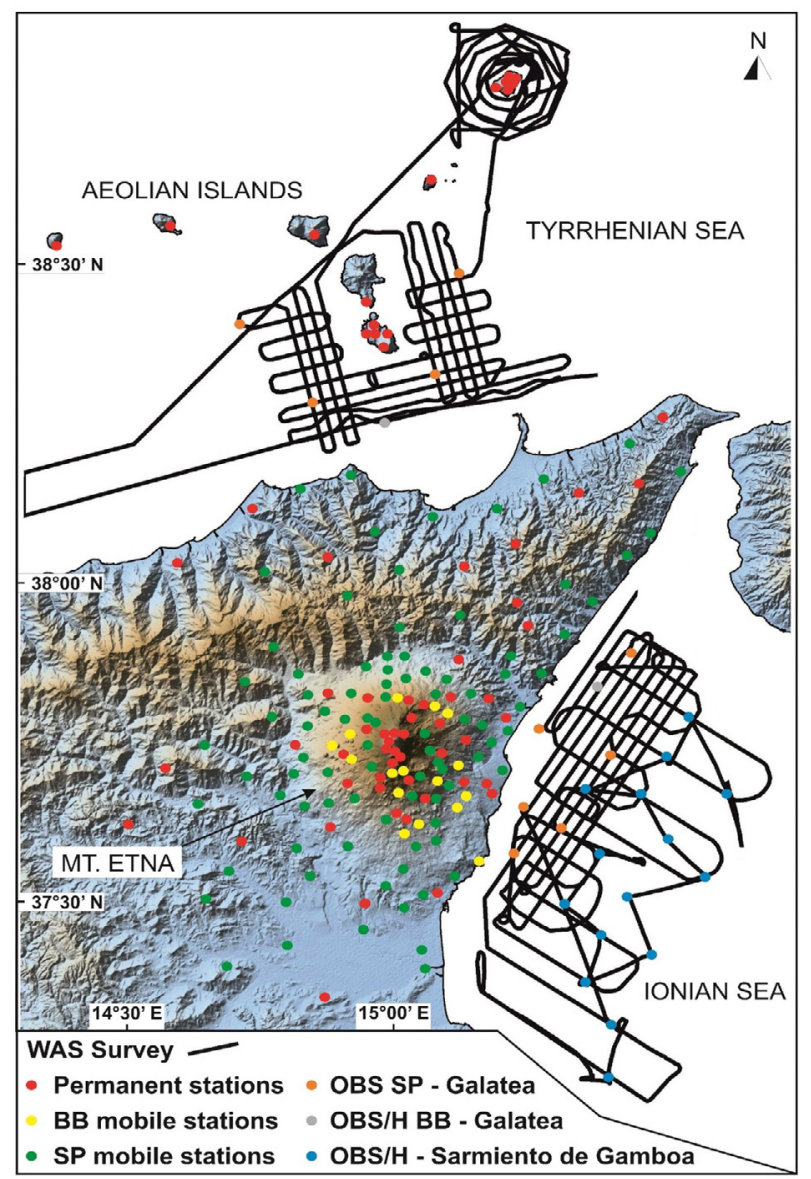

Figure 14. WAS survey carried out on board the R/V "Sarmiento de Gamboa" and location of the inland and offshore (OBSs) seismic stations. 
to the new deployment site. The main phases of the OBS activities are illustrated in Figure 13.

As regards the LC2000 SP $4 \times 4$ OBS/Hs, the instruments required about $20 \mathrm{~min}$ to descend to a depth of approximately $1000 \mathrm{~m}$, yielding a descent rate of about $45-50 \mathrm{~m} / \mathrm{min}$. The deployment procedures continued round-the-clock and were uneventful; all the OBSs were successfully positioned on the planned locations (Figure 14).

In the Ionian Sea, station spacing was approximately $8-10 \mathrm{~km}$, while in the Tyrrhenian Sea it was approximately $15 \mathrm{~km}$. Regarding recovery procedures, once released from the seafloor, the OBSs rising rate was approximately $35-40 \mathrm{~m} / \mathrm{min}$ (for the LC SP $4 \times 4$ OBS $/ \mathrm{H}$ ). GPS navigation allowed the positioning of the ship near the place where OBS was dropped to be easily recovered both in daylight and overnight (with the aid of its flashing light). Once aboard and before storing data to external hard disks, a fast QC was performed. Finally, the hardware was disassembled and stored in the racks. The network of OBSs was successfully recovered at the end of the first phase of the experiment (between July 17 to 20, 2014) by the R/V "Sarmiento de Gamboa", with the exception of the two OBS-BB/H, which were recovered in November 2014 by the R/V "Aegaeo" to record the natural seismicity for a longer time span. For the technical specifications concerning the OBSs, see Section 4.1.

\subsection{WAS}

During the first leg and the first two days of the second leg of the R/V "Sarmiento de Gamboa" cruise, about 9700 air-gun shots were performed for the WAS survey along a total route of $2650 \mathrm{~km}$, keeping the vessel speed at about 5.0-5.4 knots. Since the final goal of the WAS experiment was to gain information about the crustal velocity structure of the study area, a proper combination of maximum energy and minimum frequency content was employed. The source configuration was made by two parallel arrays of 8 Sercel G-GUN II air-guns, each kept at $15 \mathrm{~m}$ bsl, for a total volume of $5200 \mathrm{cu}$. in. (85.21 1). Shot interval was $90 \mathrm{~s}$, to allow the compressor to deliver air at the nominal 140 bar pressure and to avoid recording multiple shots during a single acquisition cycle by previous-shot induced signals (Figure 15). For further information on the technical specifications of the seismic source see Section 4.2, while for the acquisition parameters and preliminary processing methodologies of WAS data, see Ibáñez et al. [2016b, in this volume].

Ground motion was recorded by both inland and offshore seismic stations and some records were verified in real time at the INGV-OE control room. During

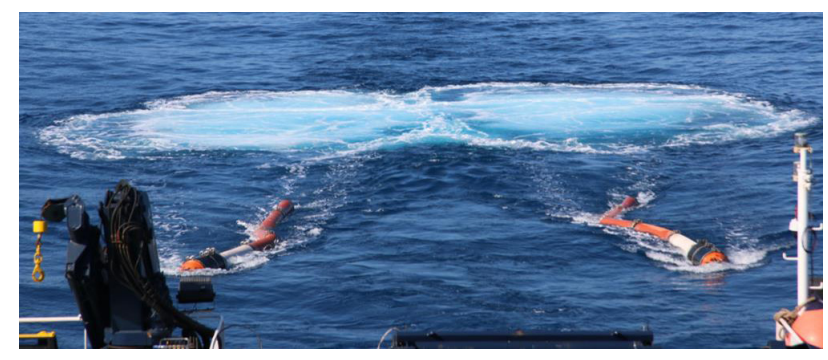

Figure 15. The two air-gun (seismic source) arrays towed by the R/V "Sarmiento de Gamboa".

the cruise, the scientific staff on board was in continuous communication with the INGV-OE, to eventually redraw the vessel routes, depending on the quality of the recorded signals. For example, signal amplitude significantly decreased when the vessel was too far from the coastline; this led to tighten the navigation grid landward, cancelling the originally planned easternmost acquisition tracks.

\subsection{MCS}

During the TOMO-ETNA experiment nearly 1410 $\mathrm{km}$ of multi-channel seismic reflection profiles (overall 76 lines; Figure 16) were acquired by the R/Vs "Sarmiento de Gamboa" and "Aegaeo", in both the Ion-

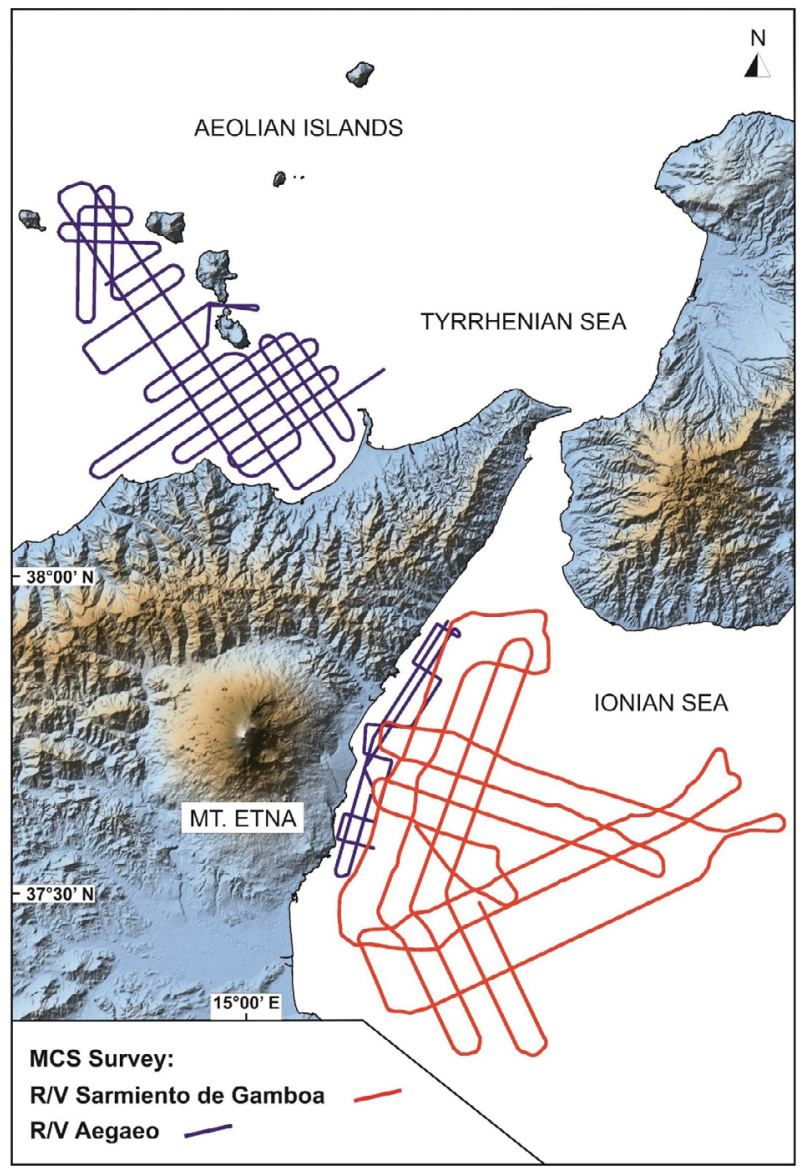

Figure 16. MCS survey tracks performed during the TOMO-ETNA experiment on board both the R/Vs "Sarmiento de Gamboa" and "Aegaeo". 
ian and Tyrrhenian Seas, to produce crustal images down to the Moho and to obtain a $2 \mathrm{D}$ velocity model that could eventually be compared with WAS results. For a detailed description of the acquisition parameters and main processing methodologies applied on MCS data, see Firetto Carlino et al. [2016, in this volume].

The second leg of the R/V "Sarmiento de Gamboa" cruise (from July 11 to 17,2014 ), was dedicated to recording about $590 \mathrm{~km}$ of MCS profiles in the Ionian Sea, using a source-receiver configuration suitable for imaging the deep structures of the crust. The MCS configuration was made of a seismic source of two parallel arrays of 8 Sercel G-GUN II air-guns kept at about $7.5 \mathrm{~m}$ of depth, which emitted a total volume of 4340 cu. in. (71.12 1), and a 240 channels (spaced at $12.5 \mathrm{~m}$ ) 3 $\mathrm{km}$ long Sercel-Sentinel digital hydrophone streamer as receiving system, maintained at about $10 \mathrm{~m}$ bsl. For the technical specifications concerning the seismic equipment, see Section 4.2. About 16,000 shots were generated at a vessel speed of 3.5-3.8 knots.

In spite of the fundamental support of the patrol ship "Levanzo" by Italian Navy to keep the acquisition tracks free from any obstacles (e.g. watercraft or submerged fishing nets), some problems were encountered with longlines fishing, which intercepted the streamer several times. Because the streamer recovering and releasing procedures took nearly seven hours, the planned acquisition routes were reduced and progressively reprogrammed for collecting data near the coast daylight, leaving the acquisition of the remaining lines overnight. Owing to this inconvenience, some lines were interrupted before the planned end and others were not linearly acquired to avoid the longlining.

During the R/V "Aegaeo" cruise (from November 19 to 26, 2014), $818 \mathrm{~km}$ of mid-shallow MCS profiles were collected in the Ionian and Tyrrhenian Seas. The seismic source was an array of one Sercel GIGUN plus one Sercel Mini GI-GUN air-guns $(210+60$ cu. in., 4.431 ), kept at about $2 \mathrm{~m}$ of depth, while the receiving system consisted in a 96 channels (spaced at $3.125 \mathrm{~m}) 300 \mathrm{~m}$ long Geometrics - GeoEel digital hydrophone streamer kept about $1.5 \mathrm{~m}$ bsl (Figure 17). Overall, nearly 36,000 air-gun shots were generated during this cruise at 3.5-3.8 knots speed. With the exception of a few air compressor malfunctions, no issues were encountered during acquisition, so the final routes did not change that much from the originally planned paths.

\subsection{Bathymetric and sub bottom profiler surveys}

Multibeam echosounder and sub bottom profiler data were simultaneously acquired during the $\mathrm{R} / \mathrm{V}$ "Sarmiento de Gamboa" cruise along the same paths

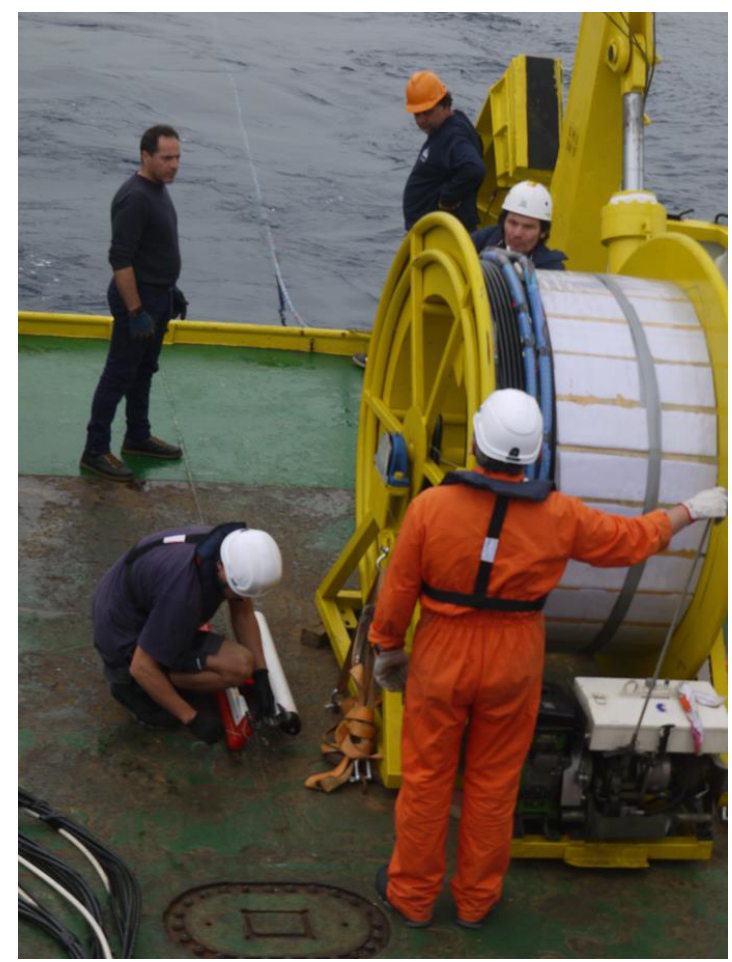

Figure 17. The hydrophone streamer release operations during the MCS survey on board the R/V "Aegaeo".

followed for both the WAS and MCS surveys (for a total length of about $3500 \mathrm{~km}$ ); moreover, two days were entirely dedicated around Stromboli Island to better detail the submerged portion of the volcano.

\subsection{Magnetic survey}

A total of $2020 \mathrm{~km}$ magnetic track lines were acquired offshore Mt. Etna on board the H/V "Galatea": $1340 \mathrm{~km}$ on a set of 64 roughly NE-SW parallel lines (with a spacing of about $300 \mathrm{~m}$ ) and 6 orthogonal tie lines during the first survey (from June 27 to July 3, 2014), $680 \mathrm{~km}$ using a series of 34 NE-SW parallel lines (with the same spacing) and 5 tie lines during the extension of the survey (from June 17 to 23, 2015) (Figure 18). The magnetic data were collected using a Geometrics G880 caesium pumped marine magnetometer (see Section 4.4) towed $180 \mathrm{~m}$ astern of the ship. The magnetic survey was carried out in correspondence of the major structural features offshore Mt. Etna, e.g. in front of the Timpe sea-cliff, on the Riposto Ridge and on the submarine extension of the Chiancone volcanoclastic fan (Figure 18). The survey was conducted at a navigation speed of about 6 knots, a good compromise between the time consuming and the accuracy of collected data. The planned magnetic survey was successfully achieved in about 48 hours of data acquisition. During the survey the track lines direction was changed a few times because of the interception along the route of some fishing nets. The resulting dataset counts more than $1,840,000$ data records. For more details and pre- 


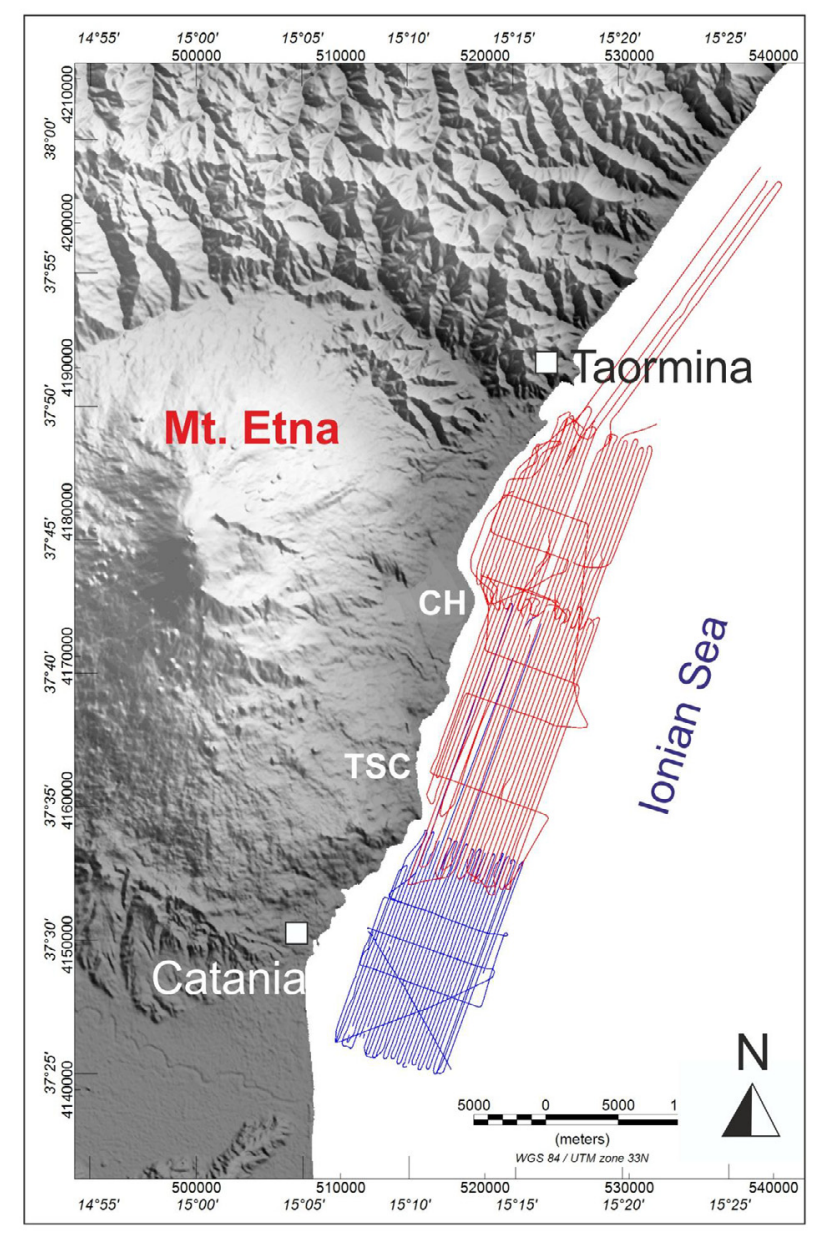

Figure 18. Track lines of the magnetic survey carried out in 2014 (red lines) and magnetic-gravity survey of 2015 (blue lines) offshore Mt. Etna volcano on board the H/V "Galatea". $\mathrm{CH}$ (Chiancone volcanoclastic fan), TSC (Timpa sea-cliff).

liminary results of the magnetic survey activity, see Cavallaro et al. [2016, in this volume].

\subsection{Gravity survey}

A total of $680 \mathrm{~km}$ of gravity track lines were acquired offshore Mt. Etna volcano (Figure 18) from June 17 to 23,2015 , on a set of 34 roughly NE-SW parallel lines (with a spacing of about $300 \mathrm{~m}$ ), 3 orthogonal tie lines and 2 oblique lines. The ship borne gravity data were collected using a gravimeter Micro G LaCoste Air-Sea Gravity System II (see Section 4.5) on board the H/V "Galatea" at a navigation speed of about 6 knots. The gravity data were acquired south of the 2014 magnetic survey, since the trend of the anomalies in the magnetic field suggested the occurrence of interesting features offshore Catania [see Cavallaro et al. 2016, in this volume]. Before beginning data acquisition, in the military harbor of Augusta, a $24 \mathrm{~h}$ long data recording test was also provided for the procedure of gravity tie. Gravity data were coupled with a proprietary GPS system (OmniSTAR) able to provide real-time correction in differential mode. The database counts overall 227,408 data.

\subsection{ROV dives}

Within the TOMO-ETNA experiment, 8 ROV dives were carried out on board the H/V "Galatea" by using a ROV Sirio by Ageotec (see Section 4.6). ROV dives covered overall 1.5 horizontal km (Figure 19), during which about 10 hours of high-resolution seafloor video were recorded. ROV dives were performed only during the morning to facilitate the equipment deployment and recovery operations. This survey imaged volcanic features on the Riposto Shoal located on the western side of the Riposto Ridge, and some complex, partially volcanic, structures on the shallow portion of the Fondachello Ridge (Figure 19). During ROV dives six seafloor samples were also collected; they were catalogued through a first lithological description. For more details and preliminary results regarding ROV dives activity, see Cavallaro et al. [2016, in this volume].

\subsection{Marine mammal safety monitoring}

The marine mammal monitoring was performed following the JNCC protocol. The observers collected data during cetacean sighting sessions, filling specific forms every day. Data recorded contained information on date, time, geo-referenced location, weather parameters, water conditions and seismic source power. In case of cetacean sighting, data included also species, numbers, sex and age class (if possible), behavioral patterns, distance and direction of travel observed; finally, eventual human activities (fishing, motorboat cruising, etc.) in the area and the relative mitigation measures implemented were also annotated.

On the basis of the above mentioned protocol, the air-gun seismic survey procedure must begin with a "soft start" or "ramp start" by gradually increasing the number of guns used and thus air volume released, over a given period, sufficiently large that animals have time to swim away before sound pressure reaches dangerous levels.

Cetacean sightings have been recorded to understand any behavioral response to seismic surveys. For this reason, changes in air volume released by air-guns have been correlated to the sightings for identifying any avoidance or ambiguous reaction of marine mammals to the shoots. For a detailed description of this monitoring activity see Monaco et al. [2016, in this volume].

\section{Conclusive remarks}

Currently, the scientific activity related to TOMOETNA experiment is focused on processing and interpreting WAS and MCS data, that will hopefully help in outlining the crustal features of the surveyed areas. The seismo-stratigraphic and structural pattern of some pe- 


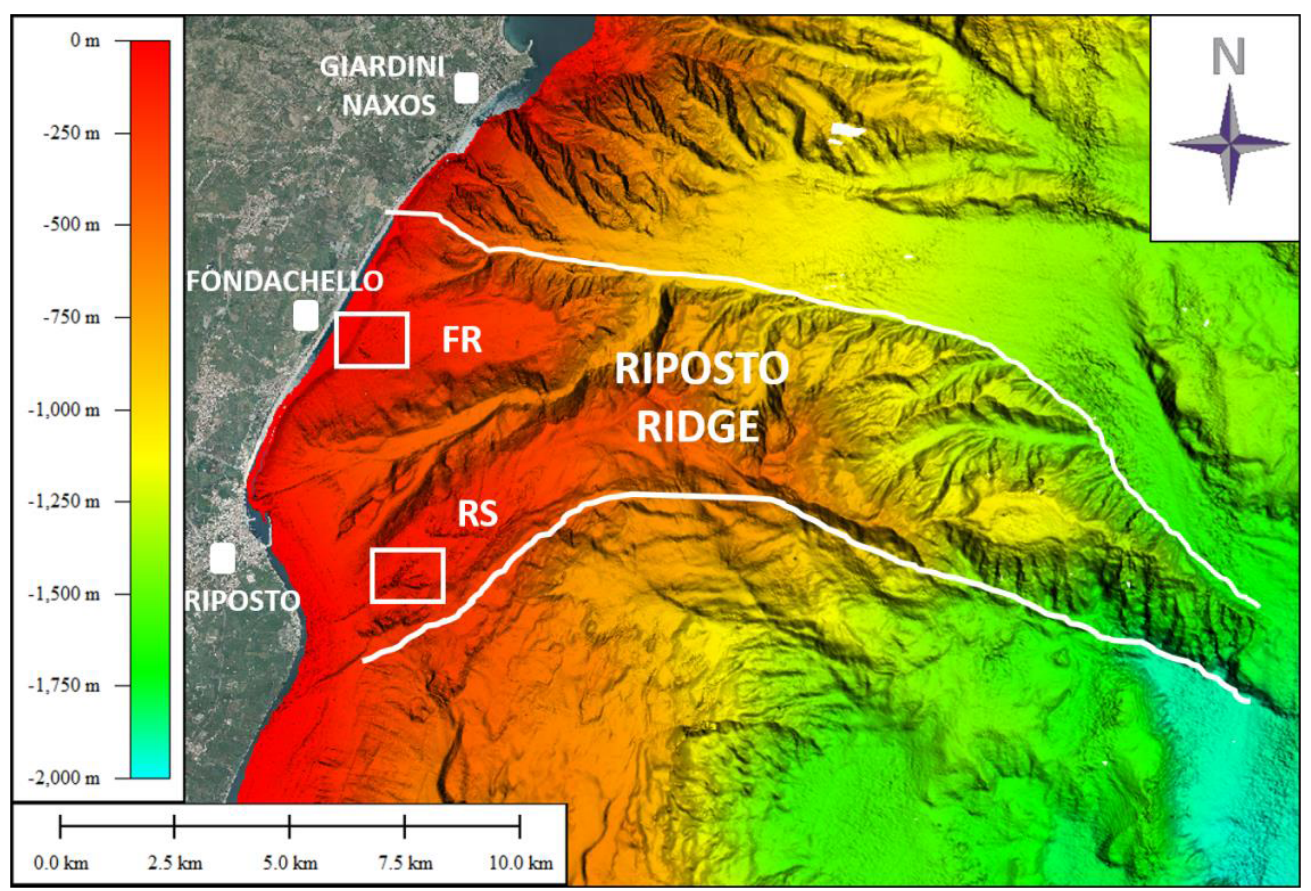

Figure 19. The areas (white boxes), on the shallow portion of the Riposto Ridge, explored by ROV dives on board the H/V "Galatea". FR (Fondachello Ridge), RS (Riposto Shoal); white lines represent the boundaries of the Riposto Ridge.

culiar portions offshore Mt. Etna and the Aeolian Islands are well imaged in the time-sections resulting from MCS data processing [Firetto Carlino et al. 2016, in this volume]. Gravity and magnetic data processing [Cavallaro et al. 2016, in this volume] is focused on providing information about density and magnetic susceptibility of the crustal bodies identified on the seismic reflection profiles, and will give independent elements to strengthening the geological interpretation.

Regarding WAS data, nearly two million seismic signals have been used for obtaining a preliminary seismic tomography [Díaz-Moreno et al. 2016, in this volume] through an automatic signals processing [García et al. 2016, in this volume] of active sources and earthquakes registered during the experiment [Barberi et al. 2016, in this volume]. However, the huge amount of data and the low signal to noise ratio of many valuable recordings, mean it is necessary to improve the accuracy of the picking and increase the number of useful travel times for enhancing the quality of 3D velocity tomography of Mt. Etna and surrounding region [García et al. 2016, in this volume].

The TOMO-ETNA experiment fostered the renewed interest of the participating institutions on the geophysical prospection of the central Mediterranean area, for understanding how the complex geodynamic setting of northeastern Sicily, spanning from the Tyrrhenian to Ionian Seas, leads to an intense seismic and volcanic activity in the region.

On the whole, it is notable that the experiment has been a complete success considering the quantity and high quality of the geophysical data collected in such a wide region, thanks to the large number of scientists and technicians involved through a complex international collaboration [Ibáñez et al. 2016a, in this volume]. Geophysical data acquired during the TOMO-ETNA experiment and INGV earthquake and volcano monitoring system will be essential to take a step forward in scientific knowledge of seismic and volcanic phenomena that impact, frequently and heavily, on such a densely populated area.

Acknowledgements. This work has been partially funded by the MED-SUV project, funding from the European Union's Seventh Program (FP7) under grant agreement No. 308665; the Spanish COCSABO project (COC-DI-2011-08); the European project EUROFLEETS2 (Seventh Framework Programme, grant agreement No. 312762) through transnational access to the research vessels "Sarmiento de Gamboa" operated by CSIC (Spain) and "Aegaeo" by HCMR (Greece). We would like to thank the following supporting institutions: Unidad de Tecnología Marina-CSIC in Barcelona (Spain); Stato Maggiore Marina (Italian Navy General Staff), CINCNAV (Command in Chief of the Fleet), Marisicilia (Navy Command of Sicily) and Coastal Guard of Riposto, Lipari and Messina. To obtain support and navigation permissions for the oceanographic cruises: Spanish Foreign Office and Italian Foreign Office. We acknowledge the two reviewers Menchu C. Comas and Luca Gasperini for their suggestions and comments that have contributed to improving the original version of the manuscript. For their contribution to making the research cruises a success, we thank the captain Rafael García Giráldez of the R/V "Sarmiento de Gamboa" (CSIC-UTM, Spain), the captain Theodoros Kanakaris of the R/V "Aegaeo" (HCRM, Greece), the Commanders Alessio Sabatini and Daniele Di Tullio of the H/V "Galatea" and the Commander Melissa Maselli of the "Levanzo" ship (Italian Navy) and their crews. We are also grateful to the ROV pilot Daniele Dell'Anna by Subonica. 


\section{References}

Argnani, A., F. Mazzarini, C. Bonazzi, M. Bisson and I. Isola (2013). The deformation offshore of Mount Etna as imaged by multichannel seismic reflection profiles, J. Volcanol. Geotherm. Res., 251, 50-64.

Barberi, G., E. Giampiccolo, C. Musumeci, L. Scarfi, V. Bruno, O. Cocina, A. Díaz-Moreno, S. Sicali, G. Tusa, T. Tuvè, L. Zuccarello, J.M. Ibáñez and D. Patanè (2016). Seismic and volcanic activity during 2014 in the region involved by TOMO-ETNA seismic active experiment, Annals of Geophysics, 59(4), S0429, doi:10.4401/ag-7082.

Cavallaro, D., L. Cocchi, M. Coltelli, F. Muccini, C. Carmisciano, M. Firetto Carlino, J.M. Ibáñez, D. Patanè, M. Filippone and E. Buttaro (2016). Acquisition procedures, processing methodologies and preliminary results of magnetic and ROV data collected during the TOMO-ETNA experiment, Annals of Geophysics, 59(4), S0431, doi:10.4401/ag-7084.

Chiocci, F.L., M. Coltelli, A. Bosman and D. Cavallaro (2011). Continental margin large-scale instability controlling the flank sliding of Etna volcano, Earth Planet. Sci. Lett., 305, 57-64.

De Gori, P., C. Chiarabba, E. Giampiccolo, C. Martínez-Arévalo and D. Patanè (2011). Body wave attenuation heralds incoming eruptions at Mt. Etna, Geology, 39, 503-506; doi:10.1130/G31993.1.

De Guidi, G., G. Lanzafame, M. Palano, G. Puglisi, A. Scaltrito and L. Scarfi (2013). Multidisciplinary study of the Tindari Fault (Sicily, Italy) separating ongoing contractional and extensional compartments along the active Africa-Eurasia convergent boundary, Tectonophysics, 588, 1-17.

Del Negro, C., and R. Napoli (2002). Ground and marine magnetic surveys of the lower eastern flank of Etna volcano (Italy), J. Volcanol. Geotherm. Res., 114, 357-372.

Díaz-Moreno, A., I. Koulakov, A. García-Yeguas, A. Jakovlev, G. Barberi, O. Cocina, L. Zuccarello, L. Scarfi, D. Patanè, I. Álvarez, L. García, C. Benítez, J. Prudencio and J.M. Ibáñez (2016). PARTOS - Passive and Active Ray TOmography Software: description and preliminary analysis using TOMO-ETNA experiment's dataset, Annals of Geophysics, 59(4), S0435, doi:10.4401/ag-7088.

Finetti, I.R. (2003). The CROP profiles across the Mediterranean Sea (CROP MARE I and II), Mem. Descr. Carta Geol. It., 62, 171-184.

Firetto Carlino, M., F. Zgur, P.P.G. Bruno, M. Coltelli, L. Sormani, D. Cavallaro, J.M. Ibáñez and D. Patanè (2016). Acquisition and preliminary analysis of multi-channel seismic reflection data, acquired during the oceanographic cruises of the TOMO-ETNA experiment, Annals of Geophysics, 59(4), S0430, doi:10.4401/ag-7083.

García, L., I. Álvarez, C. Benítez, M. Titos, Á. Bueno, S. Mota, Á. de la Torre, J.C. Segura, G. Alguacil, A. Díaz-Moreno, J. Prudencio, A. García-Yeguas, J.M. Ibáñez, L. Zuccarello, O. Cocina and D. Patanè (2016). Advances on the automatic estimation of the P-wave onset time, Annals of Geophysics, 59(4), S0434, doi:10.4401/ag-7087.

Gross, F., S. Krastel, J. Geersen, J.H. Behrmann, D. Ridente, F.L. Chiocci, J. Bialas, C. Papenberg, D. Cukur, M. Urlaub and A. Micallef (2016). The limits of seaward spreading and slope instability at the continental margin offshore Mt. Etna, imaged by high-resolution 2D seismic data, Tectonophysics, 667, 63-76.

Ibáñez, J.M., J. Prudencio, A. Díaz-Moreno, D. Patanè, G. Puglisi, B.-G. Lühr, F. Carrión, J.J. Dañobeitia, M. Coltelli, F. Bianco, E. Del Pezzo, T. Dahm, V. Willmott and V. Mazauric (2016a). The TOMO-ETNA experiment: an imaging active campaign at Mt. Etna volcano. Context, main objectives, working-plans and involved research projects, Annals of Geophysics, 59(4), S0426, doi:10.4401/ag-7079.

Ibáñez, J.M., et al. (2016b). TOMO-ETNA experiment at Etna volcano: activities on land, Annals of Geophysics, 59(4), S0427, doi:10.4401/ag-7080.

Lanzafame, G., and J.C. Bousquet (1997). The Maltese escarpment and its extension from Mt. Etna to the Aeolian Islands (Sicily): importance and evolution of a lithosphere discontinuity, Acta Vulcanologica, 9, 113-120.

Martínez-Arévalo, C., D. Patanè, A. Rietrebock and J.M. Ibáñez (2005). The intrusive process leading to the Mt. Etna 2011 flank eruption: Constrain from 3-D attenuation tomography, Geophys. Res. Lett., 32, 21309-21313.

Monaco, C., J.M. Ibáñez, F. Carrión and L.M. Tringali (2016). Cetacean behavioral responses to noise exposure generated by seismic surveys: how to mitigate better?, Annals of Geophysics, 59(4), S0436, doi:10.4401/ag-7089.

Nicolich, R., M. Laigle, A. Hirn, L. Cernoboria and J. Gallartd (2000). Crustal structure of the Ionian margin of Sicily: Etna volcano in the frame of regional evolution, Tectonophysics, 329, 121-139.

Pareschi, M.T., E. Boschi, F. Mazzarini and M. Favalli (2006). Large submarine landslides offshore Mt. Etna, Geophys. Res. Lett., 33, L13302; doi:10.1029/ 2006 GL026064.

Patanè, D., G. Barberi, O. Cocina, P. De Gori and C. Chiarabba (2006). Time-resolved seismic tomography detects magma intrusions at Mount Etna, Sci- 
ence, 313, 821-823.

Patanè, G., I. Agostino, S. La Delfa and R. Leonardi (2009). Evolution of volcanism around the eastern sector of Mt. Etna, inland and offshore, in the structural framework of eastern Sicily, Phys. Earth Planet. Int., 173, 306-316.

Patanè, D., M. Aliotta, A. Cannata, C. Cassisi, M. Coltelli, G. Di Grazia, P. Montalto and L. Zuccarello (2011). Interplay between Tectonics and Mount Etna's Volcanism: Insights into the Geometry of the Plumbing System, In: Uri Schattner (ed.), New Frontiers in Tectonic Research-At the Midst of Plate Convergence, 73-104; ISBN 978-953-307-594-5.

Polonia, A., L. Torelli, P. Mussoni, L. Gasperini, A. Artoni and D. Klaeschen (2011). The Calabrian Arc subduction complex in the Ionian Sea: Regional architecture, active deformation, and seismic hazard, Tectonics, 30, TC5018; doi:10.1029/2010TC002821.

${ }^{\star}$ Corresponding author: Mauro Coltelli, Istituto Nazionale di Geofisica e Vulcanologia, Sezione di Catania, Osservatorio Etneo, Catania, Italy; email: mauro.coltelli@ingv.it. 